\title{
Drugs of Abuse and Their Impact on Viral Pathogenesis
}

\author{
Jason T. Blackard ${ }^{1,2, *}$ a and Kenneth E. Sherman ${ }^{1,2}$
}

1 Division of Digestive Diseases, Department of Internal Medicine, University of Cincinnati College of Medicine, Cincinnati, OH 45267-0595, USA

2 Center for Addiction Research, University of Cincinnati College of Medicine, Cincinnati, OH 45267-0595, USA

* Correspondence: jason.blackard@uc.edu; Tel.: +1-513-558-4389; Fax: +1-513-558-1744

check for updates

Citation: Blackard, J.T.; Sherman, K.E. Drugs of Abuse and Their Impact on Viral Pathogenesis. Viruses 2021, 13, 2387. https://doi.org/ $10.3390 /$ v13122387

Academic Editors: Shyamasundaran Kottilil, Bhawna Poonia and Lydia S. Y. Tang

Received: 25 October 2021

Accepted: 27 November 2021

Published: 29 November 2021

Publisher's Note: MDPI stays neutral with regard to jurisdictional claims in published maps and institutional affiliations.

Copyright: (c) 2021 by the authors. Licensee MDPI, Basel, Switzerland. This article is an open access article distributed under the terms and conditions of the Creative Commons Attribution (CC BY) license (https:// creativecommons.org/licenses/by/ $4.0 /)$.

\begin{abstract}
Commonly misused substances such as alcohol, cocaine, heroin, methamphetamine, and opioids suppress immune responses and may impact viral pathogenesis. In recent years, illicit use of opioids has fueled outbreaks of several viral pathogens, including the human immunodeficiency virus (HIV), hepatitis B virus (HBV), and hepatitis C virus (HCV). This review focuses on the myriad of mechanisms by which drugs of abuse impact viral replication and disease progression. Virus-drug interactions can accelerate viral disease progression and lead to increased risk of virus transmission.
\end{abstract}

Keywords: drug use; opioid; HIV; hepatitis B virus; hepatitis C virus

\section{Drug Use Morbidity and Mortality in the US}

There were over 19 million people aged 18 or older with substance use disorder (SUD) in the United States in 2019 [1]. Frequently misused substances include alcohol, cocaine, heroin, marijuana (cannabis), tobacco, methamphetamine, and opioids. Given the sharp rise in opioid-related deaths in recent years, this review focuses on opioids and their interactions with common viral pathogens, such as the human immunodeficiency virus (HIV), hepatitis B virus (HBV), and hepatitis $\mathrm{C}$ virus (HCV).

Rates of drug overdose deaths have increased significantly in recent years [2,3]. From 2016 to 2017, more than 142,000 Emergency Department visits were suspected opioidinvolved overdoses [4]. Among the 70,000+ drug overdose deaths in 2017,67.8\% involved an opioid [5]. In $2019,70.6 \%$ of drug overdose deaths involved opioids, while $51.5 \%$ involved synthetic opioids [6]. Contributing to these increased deaths is the dramatic increase in the availability of heroin and illicitly manufactured fentanyl and fentanyl analogs [7-12].

\section{Drug Use and Immune Function}

Several commonly misused substances suppress immune responses (reviewed in $[13,14]$ ). Possible mechanisms include impaired function of natural killer cells, $\mathrm{T}$ cells, B cells, neutrophils, dendritic cells, and/or macrophages, altered expression of cytokines and chemokines, and the weakened integrity of the intestinal barrier, all of which contribute to decreased ability to control pathogens and limit their subsequent clearance. Evidence of the immunosuppressive effects of drug use are further supported by epidemiologic studies demonstrating an increased rate of infections amongst persons with SUD [15-17].

\section{Common Viral Infections Associated with Drug Use}

Drug use-particularly the opioid pandemic - has fueled outbreaks of several viral pathogens. Perhaps the most well-known example occurred in Scott County, Indiana, in 2015. In an area that had previously recorded approximately five new HIV cases annually, over 200 people were diagnosed with HIV in less than one year [18,19]. Most individuals lived in rural communities, were under 40 years of age, white, and nearly half were women. A total of $80 \%$ reported injection drug use. Among those, all reported dissolving and 
injecting oxymorphone tablets. It was subsequently reported that most individuals were also co-infected with HCV [20]. Increases in HIV and/or viral hepatitis associated with injection drug use have been noted in several other settings [21-27]. A meta-analysis found that $17.8 \%$ of persons who inject drugs (PWIDs) were living with $\mathrm{HIV}, 52.3 \%$ were $\mathrm{HCV}$ seropositive, and $9.1 \%$ were HBV surface antigen positive [28]. Thus, it is not surprising that rises in viral infections associated with injection drug use-frequently involving opioids-have been noted internationally as well [29-34].

\section{Opioids}

There are three main types of opioids. Natural opiates are found in plants and include morphine and codeine. Semi-synthetic opioids are those created in laboratory settings from natural opiates and include hydromorphone, hydrocodone, and oxycodone, as well as heroin, which is made from morphine. Synthetic opioids include fentanyl, fentanyl analogs, buprenorphine, methadone, and tramadol. Endogenous opioid peptides are also responsible for a plethora of physiological functions and include endorphins, enkephalins, and dynorphins.

Opioid family receptors are classified as $\mu$-opioid (MOR), $\delta$-opioid (DOR), $k$-opioid (KOR), and nociceptin/orphanin (ORL) receptors [35]. When an opioid receptor is activated, adenylyl cyclase is inhibited, leading to the activation of $\mathrm{K}^{+}$channels and the reduced conductance of $\mathrm{Ca}^{2+}$ channels. Opioid receptors also activate mitogen-activated protein kinases and phospholipase C-mediated signaling, leading to the formation of IP3 and diacyl glycerol. The activation or inhibition of downstream signaling cascades thus facilitates the intrinsic effects of opioids [36,37].

\section{Opioids and HIV}

Opioid receptors are expressed on a variety of immune cells, such as lymphocytes, macrophages, neutrophils, and monocytes [38,39]. Therefore, the interactions between opioids/opioid receptors and HIV are important to investigate (Figure 1). Endogenous opioid peptides enhance HIV expression. For instance, the $\beta$-endorphin enhanced viral protein production and long terminal repeat (LTR) activation in microglia [40]. Similarly, endomorphin-1 increased HIV expression in mixed glial/neuronal, as well as microglial, cell cultures [41], and dynorphin upregulated HIV expression in fetal brain co-cultures [42] However, subsequent studies have not evaluated the role of endogenous opioid peptides on HIV disease progression in vivo.

Squinto et al. first reported that morphine activated the HIV LTR in human neuroblastoma cells [43]. Subsequent studies showed increased HIV replication with several cell types. Morphine increased HIV expression in promonocyte/fetal brain cell co-cultures, as well as primary cultures of Kupffer cells [44,45]. Morphine also triggered viral reactivation in latently-infected lymphocytes [46]. Interestingly, Wang et al. demonstrated that morphine withdrawal also enhanced HIV replication within peripheral blood lymphocytes, as well as T cell lines in vitro [47]. The neuropeptide substance P (SP) enhanced viral replication in a dose-dependent manner, and an SP antagonist inhibited the effect of morphine withdrawal on HIV replication. HIV LTR activation was also increased in cells undergoing morphine withdrawal. The same group reported that morphine upregulated chemokine receptor expression, downregulated $\beta$ chemokine production, inhibited the expression of interferons (IFNs), IFN-inducible genes, and regulators of the Janus Kinase signal transducer and activator of transcription (JAK-STAT) signaling pathway, and decreased expression of anti-HIV microRNAs, while also increasing HIV expression in blood monocyte-derived macrophages and neonatal macrophages [48-51]. Morphine withdrawal also enhanced HIV expression within macrophages and inhibited expression of multiple viral inhibitory factors [52]. Additionally, Balinang et al. also demonstrated increased HIV replication in neural progenitor cells in the presence of morphine [53]. Notably, HIV proteins also synergize with morphine to increase the expression of opioid receptors, alter cell cycle regulation, and exacerbate neurotoxicity and neuroinflammation [54-60]. 


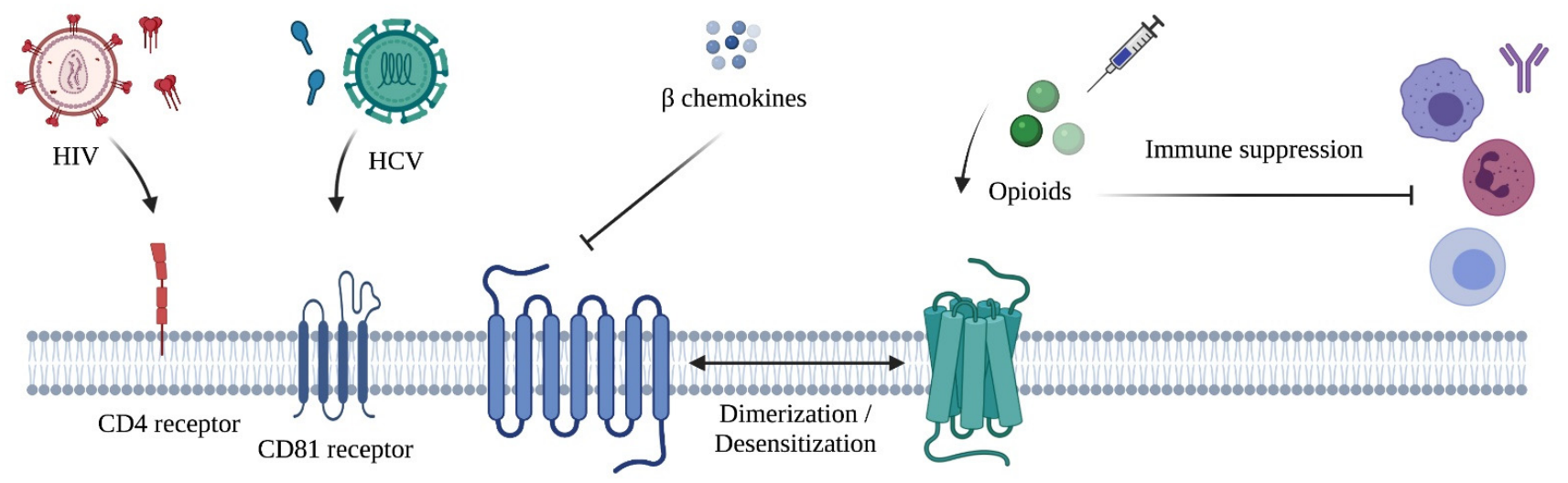

Chemokine receptor Mu opioid receptor
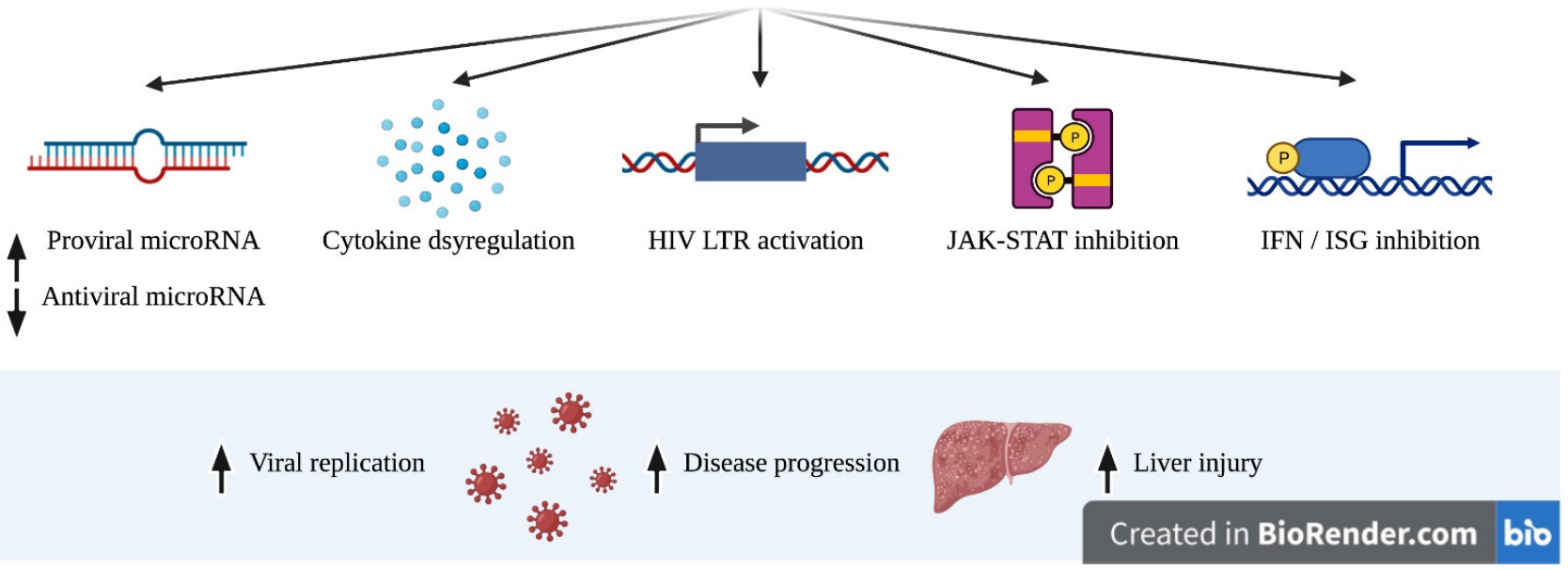

Figure 1. Mechanisms of virus-drug interactions that lead to increased viral replication and accelerated disease progression for HIV and HCV, and/or liver injury.

Using an in vitro HIV-CD4+ T cell system, Liang et al. showed that morphine treatment induced more drug-resistant mutations under selective pressure from antiretroviral drugs and shortened the generation time for such mutations compared to controls treated with only antiretroviral drugs [61]. The inhibitory effects of antiretroviral therapies on HIV replication in primary astrocytes in vitro were also attenuated by morphine [62]. Morphine influences antiretroviral drug concentration in a drug and cell type-dependent manner [57], although the in vivo significance of these findings remains to be determined. In the simian immunodeficiency virus (SIV) model, morphine alters the fecal microbiome and expression of microbial metabolites and reduces the CD4+ T cell reservoir in lymphoid tissues, while increasing the microglia/macrophage reservoir in the central nervous system $[63,64]$. There are no published reports on whether another natural opioid — codeine- has similar effects on HIV infection/replication.

Of the semi-synthetic opioids, data on their impact on HIV pathogenesis are only available for heroin (heroin triggered HIV reactivation in latently-infected lymphocytes in vitro) [46]. Others have demonstrated that heroin enhanced HIV expression in macrophages, suppressed IFNs, and inhibited several anti-HIV microRNAs [51,65]. Altered microRNA expression was also confirmed in peripheral blood mononuclear cells (PBMCs) and/or macrophages from heroin-dependent persons $[65,66]$. In a large cohort study, HIV-infected PWIDs had higher plasma HIV RNA levels than non-PWIDs, and PWIDs expressed lower levels of host restriction factors such as TRIM5 $\alpha$, TRIM22, ABOBEC3G, and IFNs than individuals with no drug use [67].

Methadone and buprenorphine are widely used for the treatment of opioid addiction. Patient-based studies investigating their impact on HIV pathogenesis are lacking. However, 
in vitro studies indicated that methadone enhanced HIV replication within fetal microglia and blood monocyte-derived macrophages, and increased replication in latently-infected PBMCs [68]. Methadone increased expression of CCR5 in monocyte-derived macrophages. A subsequent study by the same group found that methadone also increased HIV expression in primary macrophages and reduced expression of IFNs, IFN-stimulated genes, and several anti-HIV microRNAs [69].

Retention on buprenorphine treatment was associated with maximal HIV suppression in opioid-dependent persons [70], although there are no reports on whether buprenorphine directly impacts HIV levels in vivo. A recent study found that buprenorphine resulted in more than an eight-fold increase of in vitro infection of PBMCs from uninfected individuals with an HIV reporter virus [71]. In contrast, in a murine model of HIV, viral levels were not increased, although cognitive impairment was reduced in the presence of buprenorphine [72].

Despite the significant contribution of synthetic opioids such as fentanyl to the current opioid crisis, data evaluating the potential association of fentanyl or fentanyl analogs on HIV disease are limited. We recently reported preliminary data suggesting that fentanyl increases HIV replication via enhanced expression of the CCR5 and CXCR4 chemokine coreceptors in several cell types [73,74]. Nonetheless, the impacts of other synthetic opioids on HIV pathogenesis remain to be explored.

\section{Opioid Receptor/Chemokine Receptor Interactions}

It is well established that, like chemokines, $\mu-, \delta$-, and $\kappa$-opioids induce chemotactic responses in monocytes and neutrophils [75-78]. It has also been shown that the activation of mu- and delta-opioid receptors leads to the heterologous desensitization of chemokine receptors (reviewed in [79]). Thus, opioid receptor-chemokine receptor interactions and desensitization by opioid agonists may have important implications for HIV pathogenesis. Several groups have sought to antagonize opioid receptor-chemokine receptor interactions as a novel therapeutic strategy to limit HIV replication. Akgün et al. synthesized a bivalent MOR agonist/CCR5 antagonist that exhibited significant anti-nociception in mice [80]. This bivalent compound was around 3500 times more potent than a mixture of the MOR agonist and CCR5 antagonist monovalent ligands. Arnatt et al. developed a different bivalent compound targeting the MOR-CCR5 heterodimer [81]. Exposure to the bivalent ligand significantly reduced HIV p24 levels in PBMCs, macrophages, and primary astrocytes. This group subsequently developed a bivalent MOR-CXCR4 antagonist that is around 150 times more potent than monovalent controls at inhibiting HIV entry [82], and have recently reported additional bivalent MOR-CCR5 ligands with potent anti-HIV activity [83].

\section{Stimulants and HIV}

Stimulants such as cocaine and methamphetamine may alter HIV pathogenesis and have been reviewed in detail elsewhere [84,85]. For instance, stimulant use is associated with higher HIV RNA levels and greater CD4+ T cell decline [86-88]. In vitro, cocaine enhances HIV transcription through the altered expression of NFKB, mitogen- and stressactivated kinase 1 (MSK1) p38 mitogen-activated protein kinase (p38 MAPK), and/or initiation and elongation factors [89-91]. Cocaine can directly enhance HIV expression in multiple cell types including PBMCs, macrophages, CD4+ T cells, dendritic cells, microglia, and astrocytes [89,92-99]. Peterson et al. further reported that antibodies to either tumor necrosis factor alpha (TNF $\alpha)$ or transforming growth factor beta (TGF $\beta$ ) reduced the impact of cocaine on HIV replication [94]. Cocaine can also enhance HIV neuroinvasion by remodeling microvascular endothelial cells in the brain [100]. Roth et al. noted a 100- to 300-fold increase in HIV levels after cocaine administration in a murine model of HIV infection [101,102]. The mechanism by which cocaine influences HIV pathogenesis includes increased chemokine co-receptor expression, epigenetic modifications, upregulation of dendritic cell-specific intercellular adhesion molecule-3-grabbing non- 
integrin (DC-SIGN), differential MAPK expression, dysregulation of arachidonic acid and its metabolites, and/or downregulation of anti-HIV microRNAs [90,91,93,98,99,102-105].

Methamphetamine use in the US increased 43\% from 2015 to 2019 [106]. Methamphetamine use alters the immune system in a variety of ways, including altered immune cell subset number, increased pro-inflammatory cytokine production, increased CD4+ and $\mathrm{CD} 8+\mathrm{T}$ cell proliferation, enhanced CD4+ $\mathrm{T}$ cell activation and/or exhaustion, and altered immune-related signaling pathways, as reviewed elsewhere [107-110]. Population-based studies report that methamphetamine use is associated with higher HIV viral loads, higher likelihood of having detectable HIV viral loads, and/or lower CD4+ T cell counts compared to non-users [111-113]. Several in vitro studies have shown that methamphetamine and the HIV tat protein interact to alter mitochondrial dysfunction and cell death $[114,115]$. Others have demonstrated increased HIV replication in the presence of methamphetamine in multiple cell types, including blood monocyte-derived macrophages, monocyte-derived dendritic cells, neural progenitor cells, and CD4+ T cells [116-124]. The proviral effects of methamphetamine on HIV are attributed to the enhanced expression of chemokine co-receptors, decreased expression of $\beta$ chemokines, inhibition of IFN $\alpha$, upregulation of T cell activation markers, altered microRNA expression, dysregulation of signal transduction pathways, inhibition of TLR9, and activation of the HIV LTR.

\section{Alcohol and HIV}

Alcohol represents a near ubiquitous extrinsic factor that can play a role in infection, transmission, and maintenance of chronic viral infections. The World Health Organization reports that alcohol consumption contributes to 3 million deaths per year globally (WHO 2018). The 2019 National Survey on Drug Use and Health reported 139.7 million current alcohol users aged 12 and older in 2019 [125].

Alcohol can impact HIV by increased risk of infection/transmission, reduced viral suppression, and increased emergence of viral resistance to antiretroviral therapies, as well as alcohol-associated immunosuppression that increases the risk of opportunistic infections and disease progression. A meta-analysis of 10 studies reported that any alcohol consumption was associated with an increased relative risk of HIV infection, while binge drinking led to an increased relative risk of 2.2 [126]. This risk is attributable in part to the link between alcohol use, unprotected sexual intercourse, multiple sexual partners, and a prior history of sexually transmitted infections [127,128]. Recreational drug use, intimate partner violence, and depression are also recognized as co-morbidities of alcohol misuse [129].

Suppression of HIV with antiretroviral therapy has implications for the infected individual in terms of disease progression, and as well as HIV transmission to others. In a longitudinal study of patients in continuity care, the time spent with a viral load $>1500$ copies/mL was evaluated. Hazardous alcohol use, recent drug use, black race, and age were highly associated with failure to maintain an HIV $<1500$ copies/mL [130]. In the Women's Interagency HIV Study, heavy drinking was associated with failure to remain virally suppressed as well [26]. The association between failure to suppress HIV and disease progression due to alcohol is well established. However, the factors that contribute to disease progression are less clear. A detailed review of this subject suggests that alcohol may affect HIV progression through alteration of the microbiome, affecting gut permeability, and systemic activation, though not all studies report an association between heavy alcohol use and markers of progression [131]. Alcohol may increase risk of infections in persons with HIV by altered immune surveillance mechanisms. Experimental models suggest that alcohol consumption increases susceptibility to pneumococcal pneumonia [132]. The presence of alcohol use disorder is associated with greater pneumonia severity as well [133]. In vitro studies suggest that HIV gp120 and alcohol increase blood-brain barrier permeability [134]. Additionally, others have demonstrated increased $\mathrm{HIV}$ replication in the presence of alcohol in various cell types, including $\mathrm{T}$ lymphocytes, monocyte-derived macrophages, monocyte-derived dendritic cells, epithelial cells, and oral 
keratinocytes [47,135-140]. Higher alcohol-induced levels of HIV may lead to increased risk of transmission to others. The mechanisms by which alcohol enhances HIV replication include upregulation of chemokine co-receptors and inhibition of $\beta$ chemokines [137].

\section{Opioids and Viral Hepatitis}

Opioid receptors are expressed in the liver where they are important mediators of liver disease progression [141-147]. Hepatic stellate cells (HSCs) are major contributors to liver fibrosis and express multiple opioid receptors [141,142,144-146,148]. However, less is known about the impact of opioids on HCV and liver disease (Figure 1). In vitro studies demonstrated that morphine, heroin, and methamphetamine enhance HCV replication [149-153]. We recently reported that fentanyl increased replication of HCV and HBV in hepatocytes [73]. The addition of fentanyl also resulted in significant apoptosis. RNA sequencing identified multiple hepatocyte genes that were differentially regulated by fentanyl, including those related to apoptosis, the antiviral interferon response, chemokine signaling, and NFKB signaling. As higher virus levels are associated with pathogenesis and virus transmission, additional research is essential to our understanding of opioid-virus pathogenesis and for the development of new and optimized treatment strategies. However, there are no data on HCV RNA levels and/or markers of liver damage in fentanyl-using populations. Similarly, there are no published reports evaluating HCV or HBV attachment or entry factors by fentanyl or other opioids. While multiple microRNAs stimulate or suppress HCV replication [154], studies of opioid HCV-miRNA interactions are absent from the literature.

\section{Stimulants and Viral Hepatitis}

As with HIV, stimulants such as cocaine and methamphetamine may alter the pathogenesis of viral hepatitis. However, data regarding the influence of cocaine on viral hepatitis in at-risk populations are sparse. While cocaine use is associated with HCV infection and the presence of HCV viremia, the impact of cocaine on HCV RNA levels or treatment response rates is less clear [155-157]. There are conflicting data on the impact of cocaine use on liver disease $[158,159]$. Similarly, there are limited studies on the impact of cocaine use on HBV-related liver disease, although amongst US veterans with $\mathrm{HCV}$, cocaine and other drug use was associated with HBV co-infection [160].

Ye et al. demonstrated that methamphetamine increased HCV replication and inhibited hepatic IFN $\alpha$ expression in vitro [149]. Population-based studies evaluating the impact of methamphetamine on HCV RNA levels and liver disease are limited. However, methamphetamine injection is an independent predictor of incident HCV infection [161-163], and recent methamphetamine injection is associated with phylogenetic clustering of $\mathrm{HCV}$, suggesting that it plays a role in HCV transmission networks [164].

\section{Alcohol and Viral Hepatitis}

Alcohol and viral hepatitis (HBV or HCV) are important contributors to liver injury and progression to cirrhosis, leading to increased morbidity and mortality. The interaction between HCV and alcohol misuse is significant and appears to be dose- and durationdependent. For example, an analysis of National Health and Nutrition Examination Survey (NHANES) data revealed that excessive alcohol consumption was associated with a hazard ratio for liver-related mortality of around 184 compared to around 74 for HCV-infected persons not reporting excessive alcohol consumption. Liver-related mortality was increased with moderate alcohol use, as well as when HCV was present [165]. Among those cured of HCV with directing acting agents, unhealthy alcohol use remained associated with liver-related outcomes and mortality, although low-level alcohol use was not [166]. A myriad of factors could influence liver injury and disease progression among HCV-infected persons who drink alcohol. Several studies have suggested an increased quasispecies complexity of HCV associated with alcohol use $[167,168]$. In vitro studies have described increased viral replication following the exposure of permissive cells to alcohol [169]. It 
has been reported that upregulation of the microRNA-122 that facilitates HCV replication could be involved [170]. Alcohol is also associated with HCV replication in PBMCs [171]. Liver injury is also associated with the development of steatosis and free radical oxidative stress, both of which are increased in conjunction with HCV and alcohol exposure [172].

The impact of alcohol on HBV is poorly understood. Yet, alcohol consumption increases HBV surface antigen (HBsAg) and viral DNA in transgenic mice [173], supporting a previous study demonstrating increased HBsAg levels in HepG2 cells in the presence of ethanol [174]. Nonetheless, cohort-based studies evaluating the impact of alcohol on HBV-specific liver disease are lacking.

\section{Tobacco, Cannabis, and Viral Infections}

Among persons with HIV, the prevalence of cigarette smoking is estimated at $40 \%$ to $70 \%$ (reviewed in $[175,176])$. Multiple studies have reported that cigarette smoke exposure is associated with increased HIV replication, lower CD4+ T cell counts, immune activation, oxidative stress, and/or decreased adherence or response to antiretroviral therapy (ART) [177-179]. Smoking/nicotine also enhances HIV replication in macrophages, T lymphocytes, and/or microglia [180-184]. Ranjit et al. observed a three- to four-fold increase in HIV replication in macrophages exposed to benzo(a)pyrene-a major carcinogen found in cigarettes. The impact of cannabis use on HIV is less clear with some studies reporting a reduced adherence to ART and missed clinical appointments, while others reported benefi$\mathrm{cial} /$ no impact on virus levels [185-189]. Notably, given its potential anti-inflammatory properties, cannabis has been offered as a potential treatment for addiction, as well as for neuroinflammation associated with HIV [190,191].

Recent reviews show cannabis use may impact liver disease [192]. While some studies have reported that cannabis use was associated with liver fibrosis, other studies showed little to no effect. Cannabis use may also be associated with reduced hepatic steatosis [193].

\section{Drugs of Abuse and SARS-CoV-2}

The ongoing SARS-CoV-2/COVID-19 pandemic has raised considerable concern about its potential negative impact on persons with SUD [194,195]. Social isolation and stress increased with lockdowns during the pandemic. Addiction services and treatment options were also severely limited to align with new social distancing norms. Recent reports now confirm that drug overdose deaths increased during the COVID-19 pandemic [196-199]. Wang et al. recently reported that persons with SUD were at significantly increased risk for COVID-19 and worse outcomes [200]. Fentanyl use also increased during the COVID-19 pandemic [201,202]. COVID-19 mortality may be exacerbated in persons with SUD for several reasons, including downregulation of interferon expression, development of pulmonary edema, increased thrombotic factors, and increased expression of angiotensinconverting enzyme 2 (ACE2) (reviewed in [203], although data to support these potential mechanistic interactions are quite limited currently). However, the acute nature of infection with SARS-CoV-2 may prove challenging for evaluating how drugs of abuse impact SARSCoV-2/COVID-19 pathogenesis in vivo.

\section{Recommendations for Additional Research}

There are multiple future research opportunities to consider related to drugs of abuse and chronic viral infections. Firstly, side-by-side comparison of multiple drugs of abuse and their impact on viral replication in vitro is essential using standardized drug doses, established timings of drug exposure, and cell types that are relevant to the viral life cycle and the overall disease progress in vivo. Secondly, polysubstance abuse is quite common in persons with substance use disorders. While this clearly complicates study design and data analysis, the impact of polysubstance abuse compared to single drugs of abuse is not commonly considered in well-characterized clinical cohorts with viral infections and co-infections. Thirdly, the opioid antagonists naloxone and naltrexone can limit the increased viral replication brought about by distinct drugs of abuse in vitro $[48,50,65,153,204-208]$. Furthermore, a recent clini- 
cal trial demonstrated that extended-release naltrexone improves HIV viral suppression, thus suggesting its potential role in the treatment of SUD in persons with chronic viral infections [209]. Similarly, high rates of HCV clearance were achieved with combined direct-acting antivirals and opioid agonist therapy in HCV-positive PWIDs [210]. Thus, increased availability and utilization of opioid antagonists may have beneficial impacts on the most vulnerable and at-risk populations. Nonetheless, the potential effects of these agents on synthetic opioid-mediated virus replication have not been evaluated to date in vitro or in at-risk patient populations. Fourthly, given their central role in HIV pathogenesis, as well as liver disease, and the possibility of opioid receptor-chemokine receptor interactions, several groups have sought to antagonize these interactions as a novel therapeutic strategy to limit HIV replication. Yet, this strategy could be extended to include liver disease caused by alcohol, $\mathrm{HBV}$, and/or HCV. A more robust understanding of the complex interactions between opioids, viruses, and the chemokine system could facilitate the optimization of therapeutic options for patients with SUD and lead the to the development of novel therapeutic strategies for multiple diseases that are common in PWIDs. Fifthly, the interactions of drugs of abuse with antiretroviral therapies for HIV or direct-acting agents for HCV are largely known, as reviewed elsewhere (reviewed in [211-213]). However, progress towards the development of new antiviral drugs, as well as new drug formulations, and the creation of new, distinct drugs of abuse, such as fentanyl analogs, requires careful study. Moreover, the impact of viral infections on drug-drug interactions and drug metabolism must be considered. Sixthly, the human T-lymphotropic virus type 1 (HTLV-1) which infects around 10 million people globally can lead to adult T-cell leukemia/lymphoma and HTLV-associated myelopathy/tropical spastic paraparesis (reviewed in [214]). Given its routes of transmission, co-infections with HIV, HBV, and $\mathrm{HCV}$ are relatively common and would likely impact persons with SUD/OUD (opioid use disorder). However, there are almost no published data on the impact of drugs of abuse on HTLV-1 pathogenesis. Thus, this represents an excellent focus for future research.

\section{Conclusions}

Chronic viral infections like HIV, hepatitis B, and hepatitis $C$ have a significant impact on individuals, and the health of societies as a whole. Though suppressive or curative strategies are available for these infectious diseases, their efficacy and impact may be limited by the use or misuse of drugs and/or alcohol through a variety of interconnected mechanisms. These include effects on viral replication, immune-mediated clearance, and medication adherence. The outcomes of these interactions can lead to disease progression (i.e., CD4+ T cell decline, immune activation, and/or increased hepatic fibrosis/cirrhosis) and to increased risk of transmission. While virus-drug interactions have been explored for some drugs of abuse, there are limited data for others. Additional research into the complex interactions between drugs of abuse and viral pathogenesis must simultaneously occur at the level of basic research in vitro, as well as in vivo in large cohort studies that are sufficiently powered to permit the analysis of subsets of individuals experiencing these disease modifiers.

Author Contributions: Conceptualization: J.T.B. and K.E.S.; writing—original draft preparation: J.T.B. and K.E.S.; writing - review and editing: J.T.B. and K.E.S.; funding acquisition: J.T.B. and K.E.S. All authors have read and agreed to the published version of the manuscript.

Funding: This work was supported by the National Institute of Drug Abuse (grant number DA048439 to J.T.B.).

Acknowledgments: This work was supported by the National Institute of Drug Abuse (grant number DA048439 to J.T.B.). The authors would also like to thank Susan Rouster and Heidi Meeds for the editing of this review.

Conflicts of Interest: The authors have no conflict of interest to report. 


\section{References}

1. Substance Abuse and Mental Health Services Administration. The National Survey on Drug Use and Health: 2019. Available online: https:/ / www.samhsa.gov/data/sites/default/files/reports/rpt29392/Assistant-Secretary-nsduh2019_presentation/ Assistant-Secretary-nsduh2019_presentation.pdf (accessed on 22 August 2021).

2. Shiels, M.S.; Freedman, N.D.; Thomas, D.; Berrington de Gonzalez, A. Trends in US drug overdose deaths in non-Hispanic black, Hispanic, and non-Hispanic white persons, 2000-2015. Ann. Intern. Med. 2018, 168, 453-455. [CrossRef]

3. Jalal, H.; Buchanich, J.M.; Roberts, M.S.; Balmert, L.C.; Zhang, K.; Burke, D.S. Changing dynamics of the drug overdose epidemic in the United States from 1979 through 2016. Science 2018, 361, eaau1184. [CrossRef]

4. Houry, D.E.; Haegerich, T.M.; Vivolo-Kantor, A. Opportunities for Prevention and Intervention of Opioid Overdose in the Emergency Department. Ann. Emerg. Med. 2018, 71, 688-690. [CrossRef]

5. Scholl, L.; Seth, P.; Kariisa, M.; Wilson, N.; Baldwin, G. Drug and Opioid-Involved Overdose Deaths—United States, $2013-2017$. MMWR Morb. Mortal. Wkly. Rep. 2018, 67, 1419-1427. [CrossRef]

6. Mattson, C.L.; Tanz, L.J.; Quinn, K.; Kariisa, M.; Patel, P.; Davis, N.L. Trends and geographic patterns in drug and synthetic opioid overdose deaths-United States, 2013-2019. Morb. Mortal. Wkly. Rep. 2021, 70, 202. [CrossRef]

7. O'Donnell, J.K.; Gladden, R.M.; Seth, P. Trends in Deaths Involving Heroin and Synthetic Opioids Excluding Methadone, and Law Enforcement Drug Product Reports, by Census Region-United States, 2006-2015. MMWR Morb. Mortal. Wkly. Rep. 2017, 66, 897-903. [CrossRef]

8. Somerville, N.J.; O’Donnell, J.; Gladden, R.M.; Zibbell, J.E.; Green, T.C.; Younkin, M.; Ruiz, S.; Babakhanlou-Chase, H.; Chan, M.; Callis, B.P.; et al. Characteristics of fentanyl overdose-Massachusetts, 2014-2016. Morb. Mortal. Wkly. Rep. 2017, 66, 382-386. [CrossRef]

9. Rudd, R.A.; Aleshire, N.; Zibbell, J.E.; Gladden, R.M. Increases in Drug and Opioid Overdose Deaths-United States, $2000-2014$. Arab. Archaeol. Epigr. 2016, 64, 1378-1382. [CrossRef]

10. Jones, C.M.; Logan, J.; Gladden, R.M.; Bohm, M.K. Vital signs: Demographic and substance use trends among heroin usersUnited States, 2002-2013. MMWR Morb. Mortal. Wkly. Rep. 2015, 64, 719.

11. Springer, Y.P.; Gladden, R.M.; O'Donnell, J.; Seth, P. Notes from the Field: Fentanyl Drug Submissions-United States, $2010-2017$. MMWR Morb. Mortal. Wkly. Rep. 2019, 68, 41-43. [CrossRef]

12. O'Donnell, J.; Gladden, R.M.; Goldberger, B.A.; Mattson, C.L.; Kariisa, M. Notes from the Field: Opioid-Involved Overdose Deaths with Fentanyl or Fentanyl Analogs Detected-28 States and the District of Columbia, July 2016-December 2018. MMWR Morb. Mortal. Wkly. Rep. 2020, 69, 271-273. [CrossRef]

13. Plein, L.M.; Rittner, H.L. Opioids and the immune system—friend or foe. Br. J. Pharmacol. 2018, 175, 2717-2725. [CrossRef]

14. Roy, S.; Ninkovic, J.; Banerjee, S.; Charboneau, R.G.; Das, S.; Dutta, R.; Kirchner, V.A.; Koodie, L.; Ma, J.; Meng, J.; et al. Opioid Drug Abuse and Modulation of Immune Function: Consequences in the Susceptibility to Opportunistic Infections. J. Neuroimmune Pharmacol. 2011, 6, 442-465. [CrossRef]

15. Scheidegger, C.; Zimmerli, W. Infectious Complications in Drug Addicts: Seven-Year Review of 269 Hospitalized Narcotics Abusers in Switzerland. Rev. Infect. Dis. 1989, 11, 486-493. [CrossRef]

16. Sánchez-Carbonell, X.; Vilaregut, A. A 10-year follow-up study on the health status of heroin addicts based on official registers. Addiction 2001, 96, 1777-1786. [CrossRef]

17. DeGruttolla, V.; Seage, G.; Mayer, K.; Horsburgh, C. Infectiousness of HIV between male homosexual partners. J. Clin. Epidemiol. 1989, 42, 849-856. [CrossRef]

18. Strathdee, S.A.; Beyrer, C. Threading the Needle-How to Stop the HIV Outbreak in Rural Indiana. N. Engl. J. Med. 2015, 373, 397-399. [CrossRef]

19. Conrad, C.; Bradley, H.M.; Broz, D.; Buddha, S.; Chapman, E.L.; Galang, R.R.; Hillman, D.; Hon, J.; Hoover, K.W.; Patel, M.R.; et al. Community outbreak of HIV infection linked to injection drug use of oxymorphone-Indiana, 2015. Morb. Mortal. Wkly. Rep. 2015, 64, 443-444.

20. Ramachandran, S.; Thai, H.; Forbi, J.C.; Galang, R.R.; Dimitrova, Z.; Xia, G.-L.; Lin, Y.; Punkova, L.T.; Pontones, P.R.; Gentry, J.; et al. A large HCV transmission network enabled a fast-growing HIV outbreak in rural Indiana, 2015. EBioMedicine 2018, 37, 374-381. [CrossRef]

21. Zibbell, J.E.; Iqbal, K.; Patel, R.C.; Suryaprasad, A.; Sanders, K.J.; Moore-Moravian, L.; Serrecchia, J.; Blankenship, S.; Ward, J.W.; Holtzman, D.; et al. Increases in hepatitis $C$ virus infection related to injection drug use among persons aged $\leq 30$ years-Kentucky, Tennessee, Virginia, and West Virginia, 2006-2012. MWR Morb. Mortal. Wkly. Rep. 2015, 64, 453-458.

22. Evans, M.E.; Labuda, S.M.; Hogan, V.; Agnew-Brune, C.; Armstrong, J.; Karuppiah, A.B.P.; Blankinship, D.; Buchacz, K.; Burton, K.; Cibrik, S.; et al. Notes from the Field: HIV Infection Investigation in a Rural Area-West Virginia, 2017. MMWR Morb. Mortal. Wkly. Rep. 2018, 67, 257-258. [CrossRef]

23. Alpren, C.; Dawson, E.L.; John, B.; Cranston, K.; Panneer, N.; Fukuda, H.D.; Roosevelt, K.; Klevens, R.M.; Bryant, J.; Peters, P.J.; et al. Opioid Use Fueling HIV Transmission in an Urban Setting: An Outbreak of HIV Infection among People Who Inject Drugs-Massachusetts, 2015-2018. Am. J. Public Health 2020, 110, 37-44. [CrossRef]

24. Golden, M.R.; Lechtenberg, R.; Glick, S.N.; Dombrowski, J.; Duchin, J.; Reuer, J.R.; Dhanireddy, S.; Neme, S.; Buskin, S.E. Outbreak of Human Immunodeficiency Virus Infection among Heterosexual Persons Who Are Living Homeless and Inject Drugs-Seattle, Washington, 2018. MMWR Morb. Mortal. Wkly. Rep. 2019, 68, 344-349. [CrossRef] 
25. Atkins, A.; McClung, R.P.; Kilkenny, M.; Bernstein, K.; Willenburg, K.; Edwards, A.; Lyss, S.; Thomasson, E.; Panneer, N.; Kirk, N.; et al. Notes from the Field: Outbreak of Human Immunodeficiency Virus Infection among Persons Who Inject Drugs-Cabell County, West Virginia, 2018-2019. MMWR Morb. Mortal. Wkly. Rep. 2020, 69, 499-500. [CrossRef]

26. Comer, M.; Matthias, J.; Nicholson, G.; Asher, A.; Holmberg, S.; Wilson, C. Increase in acute hepatitis B infections-Pasco County, Florida, 2011-2016. Morb. Mortal. Wkly. Rep. 2018, 67, 230-231. [CrossRef] [PubMed]

27. Harris, A.M.; Iqbal, K.; Schillie, S.; Britton, J.; Kainer, M.A.; Tressler, S.; Vellozzi, C. Increases in acute hepatitis B virus infectionsKentucky, Tennessee, and West Virginia, 2006-2013. Morb. Mortal. Wkly. Rep. 2016, 65, 47-50. [CrossRef] [PubMed]

28. Degenhardt, L.; Peacock, A.; Colledge, S.; Leung, J.; Grebely, J.; Vickerman, P.; Stone, J.; Cunningham, E.B.; Trickey, A.; Dumchev, K.; et al. Global prevalence of injecting drug use and sociodemographic characteristics and prevalence of HIV, HBV, and HCV in people who inject drugs: A multistage systematic review. Lancet Glob. Health 2017, 5, e1192-e1207. [CrossRef]

29. Mendoza, M.R.; Meza-Mercado, D.; Martínez-Martínez, R.; Magis-Rodríguez, C.; Castro, A.O.; Medina-Mora, M.E. People who inject drugs (PWID) and HIV/aids cases in Mexico City: 1987-2015. Subst. Abus. Treat. Prev. Policy 2019, 14, 59. [CrossRef]

30. Hayashi, K.; Milloy, M.-J.; Lysyshyn, M.; DeBeck, K.; Nosova, E.; Wood, E.; Kerr, T. Substance use patterns associated with recent exposure to fentanyl among people who inject drugs in Vancouver, Canada: A cross-sectional urine toxicology screening study. Drug Alcohol Depend. 2018, 183, 1-6. [CrossRef]

31. Samji, H.; Yu, A.; Wong, S.; Wilton, J.; Binka, M.; Alvarez, M.; Bartlett, S.; Pearce, M.; Adu, P.; Jeong, D.; et al. Drug-related deaths in a population-level cohort of people living with and without hepatitis C virus in British Columbia, Canada. Int. J. Drug Policy 2020, 86, 102989. [CrossRef]

32. Platt, L.; Bobrova, N.; Rhodes, T.; Uusküla, A.; Parry, J.V.; Rüütel, K.; Talu, A.; Abel, K.; Rajaleid, K.; Judd, A. High HIV prevalence among injecting drug users in Estonia: Implications for understanding the risk environment. AIDS 2006, 20, 2120-2123. [CrossRef]

33. Talu, A.; Rajaleid, K.; Abel-Ollo, K.; Rüütel, K.; Rahu, M.; Rhodes, T.; Platt, L.; Bobrova, N.; Uusküla, A. HIV infection and risk behaviour of primary fentanyl and amphetamine injectors in Tallinn, Estonia: Implications for intervention. Int. J. Drug Policy 2010, 21, 56-63. [CrossRef]

34. Tavitian-Exley, I.; Maheu-Giroux, M.; Platt, L.; Heimer, R.; Uusküla, A.; Levina, O.; Vickerman, P.; Boily, M.-C. Differences in risk behaviours and HIV status between primary amphetamines and opioid injectors in Estonia and Russia. Int. J. Drug Policy 2018, 53, 96-105. [CrossRef]

35. Stevens, C. The evolution of vertebrate opioid receptors. Front. Biosci. 2009, 14, 1247-1269. [CrossRef]

36. Stein, C. Opioid receptors. Annu. Rev. Med. 2016, 67, 433-451. [CrossRef]

37. Law, P.-Y.; Wong, Y.H.; Loh, H.H. Molecular Mechanisms and Regulation of Opioid Receptor Signaling. Annu. Rev. Pharmacol. Toxicol. 2000, 40, 389-430. [CrossRef]

38. Tahamtan, A.; Tavakoli-Yaraki, M.; Mokhtari-Azad, T.; Teymoori-Rad, M.; Bont, L.; Shokri, F.; Salimi, V. Opioids and viral infections: A double-edged sword. Front. Microbiol. 2016, 7, 970. [CrossRef]

39. Banerjee, A.; Strazza, R.; Wigdahl, B.; Pirrone, V.; Meucci, O.; Nonnemacher, M. Role of mu-opioid receptors as cofactors in human immunodeificiency virus type 1 disease progression and neuorpathogenesis. J. Neurovirol. 2011, 17, 291-302. [CrossRef]

40. Sundar, K.S.; Kamaraju, L.S.; Dingfelder, J.; McMahon, J.; Gollapudi, S.; Wilson, W.H.; Kong, L.Y.; Hong, J.S.; Weiss, J.M.; Lee, J. beta-Endorphin enhances the replication of neurotropic human immunodeficiency virus in fetal perivascular microglia. $J$. Neuroimmunol. 1995, 61, 97-104. [CrossRef]

41. Peterson, P.K.; Gekker, G.; Hu, S.; Lokensgard, J.; Portoghese, P.S.; Chao, C. Endomorphin-1 potentiates HIV-1 expression in human brain cell cultures: Implication of an atypical mu-opioid receptor. Neuropharmacology 1999, 38, 273-278. [CrossRef]

42. Chao, C.C.; Gekker, G.; Hu, S.; Sheng, W.S.; Portoghese, P.S.; Peterson, P.K. Upregulation of HIV-1 expression in cocultures of chronically infected promonocytes and human brain cells by dynorphin. Biochem. Pharmacol. 1995, 50, 715-722. [CrossRef]

43. Squinto, S.P.; Mondal, D.; Block, A.L.; Prakash, O. Morphine-Induced Transactivation of HIV-1 LTR in Human Neuroblastoma Cells. AIDS Res. Hum. Retrovir. 1990, 6, 1163-1168. [CrossRef]

44. Peterson, P.K.; Gekker, G.; Hu, S.; Anderson, W.; Kravitz, F.; Portoghese, P.S.; Balfour, H.H.; Chao, C.C. Morphine amplifies HIV-1 expression in chronically infected promonocytes cocultured with human brain cells. J. Neuroimmunol. 1994, 50, 167-175. [CrossRef]

45. Schweitzer, C.; Keller, F.; Schmitt, M.P.; Jaeck, D.; Adloff, M.; Schmitt, C.; Royer, C.; Kirn, A.; Aubertin, A. Morphine stimulates HIV replication in primary cultures of human Kupffer cells. Res. Virol. 1991, 142, 189-195. [CrossRef]

46. Prottengeier, J.; Koutsilieri, E.; Scheller, C. The effects of opioids on HIV reactivation in latently-infected T-lymphoblasts. AIDS Res. Ther. 2014, 11, 17. [CrossRef]

47. Xu, D.; Fu, J.; Jin, L.; Zhang, H.; Zhou, C.; Zou, Z.; Zhao, J.-M.; Zhang, B.; Shi, M.; Ding, X.; et al. Circulating and Liver Resident CD4+CD25+ Regulatory T Cells Actively Influence the Antiviral Immune Response and Disease Progression in Patients with Hepatitis. B. J. Immunol. 2006, 177, 739-747. [CrossRef]

48. Li, Y.; Merrill, J.D.; Mooney, K.; Song, L.; Wang, X.; Guo, C.-J.; Savani, R.C.; Metzger, D.S.; Douglas, S.D.; Ho, W.-Z. Morphine Enhances HIV Infection of Neonatal Macrophages. Pediatr. Res. 2003, 54, 282-288. [CrossRef]

49. Wang, Y.; Wang, X.; Ye, L.; Li, J.; Song, L.; Fulambarkar, N.; Ho, W. Morphine Suppresses IFN Signaling Pathway and Enhances AIDS Virus Infection. PLoS ONE 2012, 7, e31167. [CrossRef]

50. Guo, C.J.; Li, Y.; Tian, S.; Wang, X.; Douglas, S.D.; Ho, W. Morphine enhances HIV infection of human blood mononuclear phagocytes through modulation of beta-chemokines and CCR5 receptor. J. Investig. Med. 2002, 50, 435-442. [CrossRef] 
51. Tang, B.; Zhang, Y.; Liang, R.; Yuan, P.; Du, J.; Wang, H.; Wang, L. Activation of the $\delta$-opioid receptor inhibits serum deprivationinduced apoptosis of human liver cells via the activation of PKC and the mitochondrial pathway. Int. J. Mol. Med. 2011, 28, 1077-1085.

52. Wang, X.; Liu, J.; Zhou, L.; Ho, W.-Z. Morphine Withdrawal Enhances HIV Infection of Macrophages. Front. Immunol. 2019, 10, 2601. [CrossRef] [PubMed]

53. Balinang, J.M.; Masvekar, R.R.; Hauser, K.F.; Knapp, P.E. Productive infection of human neural progenitor cells by R5 tropic HIV-1: Opiate co-exposure heightens infectivity and functional vulnerability. AIDS 2017, 31, 753-764. [CrossRef] [PubMed]

54. Turchan-Cholewo, J.; Dimayuga, F.O.; Ding, Q.; Keller, J.; Hauser, K.F.; Knapp, P.E.; Bruce-Keller, A.J. Cell-specific actions of HIV-Tat and morphine on opioid receptor expression in glia. J. Neurosci. Res. 2008, 86, 2100-2110. [CrossRef] [PubMed]

55. Turchan-Cholewo, J.; Dimayuga, F.O.; Gupta, S.; Keller, J.N.; Knapp, P.E.; Hauser, K.F.; Bruce-Keller, A.J. Morphine and HIV-Tat increase microglial-free radical production and oxidative stress: Possible role in cytokine regulation. J. Neurochem. 2009, 108, 202-215. [CrossRef] [PubMed]

56. Samikkannu, T.; Ranjith, D.; Rao, K.V.; Atluri, V.S.; Pimentel, E.; El-Hage, N.; Nair, M.P. HIV-1 gp120 and morphine induced oxidative stress: Role in cell cycle regulation. Front. Microbiol. 2015, 6, 614. [CrossRef]

57. Patel, S.H.; Ismaiel, O.A.; Mylott, W.R.; Yuan, M.; McClay, J.L.; Paris, J.J.; Hauser, K.F.; McRae, M. Cell-type specific differences in antiretroviral penetration and the effects of HIV-1 Tat and morphine among primary human brain endothelial cells, astrocytes, pericytes, and microglia. Neurosci. Lett. 2019, 712, 134475. [CrossRef]

58. Kim, S.; Hahn, Y.K.; Podhaizer, E.M.; McLane, V.D.; Zou, S.; Hauser, K.F.; E Knapp, P. A central role for glial CCR5 in directing the neuropathological interactions of HIV-1 Tat and opiates. J. Neuroinflamm. 2018, 15, 28. [CrossRef]

59. Chen, K.; Phan, T.; Lin, A.; Sardo, L.; Mele, A.R.; Nonnemacher, M.R.; Klase, Z. Morphine exposure exacerbates HIV-1 Tat driven changes to neuroinflammatory factors in cultured astrocytes. PLoS ONE 2020, 15, e0230563. [CrossRef]

60. Avdoshina, V.; Biggio, F.; Palchik, G.; Campbell, L.A.; Mocchetti, I. Morphine induces the release of CCL5 from astrocytes: Potential neuroprotective mechanism against the HIV protein gp120. Glia 2010, 58, 1630-1639. [CrossRef]

61. Liang, B.; Jiang, J.; Pan, P.; Chen, R.; Zhuang, D.; Zhao, F.; Chen, H.; Huang, J.; Su, Q.; Cao, C.; et al. Morphine Increases Lamivudine- and Nevirapine-Induced Human Immunodeficiency Virus-1 Drug-Resistant MutationsIn Vitro. Microb. Drug Resist. 2017, 23, 285-293. [CrossRef]

62. Rodriguez, M.; Lapierre, J.; Ojha, C.R.; Pawitwar, S.; Karuppan, M.K.M.; Kashanchi, F.; El-Hage, N. Morphine counteracts the antiviral effect of antiretroviral drugs and causes upregulation of p62/SQSTM1 and histone-modifying enzymes in HIV-infected astrocytes. J. Neurovirol. 2019, 25, 263-274. [CrossRef]

63. Sindberg, G.M.; Callen, S.E.; Banerjee, S.; Meng, J.; Hale, V.L.; Hegde, R.; Cheney, P.D.; Villinger, F.; Roy, S.; Buch, S. Morphine Potentiates Dysbiotic Microbial and Metabolic Shifts in Acute SIV Infection. J. Neuroimmune Pharmacol. 2019, 14, $200-214$. [CrossRef]

64. Acharya, A.; Olwenyi, O.A.; Thurman, M.; Pandey, K.; Morsey, B.M.; Lamberty, B.; Ferguson, N.; Callen, S.; Fang, Q.; Buch, S.J.; et al. Chronic morphine administration differentially modulates viral reservoirs in SIVmac251 infected rhesus macaque model. $J$. Virol. 2020. [CrossRef]

65. Wang, X.; Ma, T.-C.; Li, J.-L.; Zhou, Y.; Geller, E.B.; Adler, M.W.; Peng, J.-S.; Zhou, W.; Zhou, D.-J.; Ho, W.-Z. Heroin inhibits HIV-restriction miRNAs and enhances HIV infection of macrophages. Front. Microbiol. 2015, 6, 1230. [CrossRef] [PubMed]

66. Wang, X.; Sun, L.; Zhou, Y.; Su, Q.-J.; Li, J.-L.; Ye, L.; Liu, M.-Q.; Zhou, W.; Ho, W.-Z. Heroin Abuse and/or HIV Infection Dysregulate Plasma Exosomal miRNAs. J. Neuroimmune Pharmacol. 2020, 15, 400-408. [CrossRef]

67. Zhu, J.-W.; Liu, F.-L.; Mu, D.; Deng, D.-Y.; Zheng, Y.-T. Heroin use is associated with lower levels of restriction factors and type I interferon expression and facilitates HIV-1 replication. Microbes Infect. 2017, 19, 288-294. [CrossRef]

68. Li, Y.; Wang, X.; Tian, S.; Guo, C.J.; Douglas, S.D.; Ho, W. Methadone enhances human immunodeficiency virus infection of human immune cells. J. Infect. Dis. 2002, 185, 118-122. [CrossRef]

69. Wang, M.-R.; Wu, D.-D.; Luo, F.; Zhong, C.-J.; Wang, X.; Zhu, N.; Wu, Y.-J.; Hu, H.-T.; Feng, Y.; Wang, X.; et al. Methadone Inhibits Viral Restriction Factors and Facilitates HIV Infection in Macrophages. Front. Immunol. 2020, 11, 1253. [CrossRef]

70. Springer, S.A.; Qiu, J.; Saber-Tehrani, A.S.; Altice, F.L. Retention on Buprenorphine Is Associated with High Levels of Maximal Viral Suppression among HIV-Infected Opioid Dependent Released Prisoners. PLoS ONE 2012, 7, e38335. [CrossRef]

71. Gornalusse, G.G.; Vojtech, L.N.; Levy, C.N.; Hughes, S.M.; Kim, Y.; Valdez, R.; Pandey, U.; Ochsenbauer, C.; Astronomo, R.; McElrath, J.; et al. Buprenorphine Increases HIV-1 Infection In Vitro but Does Not Reactivate HIV-1 from Latency. Viruses 2021, 13, 1472. [CrossRef]

72. Jaureguiberry-Bravo, M.; Kelschenbach, J.; Murphy, A.; Carvallo, L.; Hadas, E.; Tesfa, L.; Scott, T.M.; Rivera-Mindt, M.; Cunningham, C.O.; Arnsten, J.H.; et al. Treatment with buprenorphine prior to EcoHIV infection of mice prevents the development of neurocognitive impairment. J. Leukoc. Biol. 2021, 109, 675-681. [CrossRef]

73. Kong, L.; Karns, R.; Shata, M.; Brown, J.L.; Lyons, M.S.; Sherman, K.E.; Blackard, J.T. The synthetic opioid fentanyl enhances viral replication in vitro. PLoS ONE 2021, 16, e0249581. [CrossRef]

74. Kong, L.; Karns, R.; Shata, M.T.M.; Brown, J.L.; Lyons, M.S.; Sherman, K.E.; Blackard, J.T. The synthetic opioid fentanyl increases HIV replication in vitro. In Proceedings of the HIV and Liver Disease, Jackson Hole, WY, USA.

75. Ruff, M.R.; Wahl, S.M.; Mergenhagen, S.; Pert, C.B. Opiate receptor-mediated chemotaxis of human monocytes. Neuropeptides 1985, 5, 363-366. [CrossRef] 
76. Van Epps, E.D.; Saland, L. Beta-endorphin and met-enkephalin stimulate human peripheral blood mononuclear cell chemotaxis. J. Immunol. 1984, 132, 3046-3053. [PubMed]

77. Grimm, M.C.; Ben-Baruch, A.; Taub, D.D.; Howard, O.M.Z.; Resau, J.H.; Wang, J.M.; Ali, H.; Richardson, R.; Snyderman, R.; Oppenheim, J.J. Opiates Transdeactivate Chemokine Receptors: $\delta$ and $\mu$ Opiate Receptor-mediated Heterologous Desensitization. J. Exp. Med. 1998, 188, 317-325. [CrossRef] [PubMed]

78. Rogers, T.J.; Steele, A.D.; Howard, O.M.Z.; Oppenheim, J.J. Bidirectional Heterologous Desensitization of Opioid and Chemokine Receptors. Ann. N. Y. Acad. Sci. 2000, 917, 19-28. [CrossRef] [PubMed]

79. Steele, A.D.; Szabo, I.; Bednar, F.; Rogers, T.J. Interactions between opioid and chemokine receptors: Heterologous desensitization. Cytokine Growth Factor Rev. 2002, 13, 209-222. [CrossRef]

80. Akgun, E.; Javed, M.I.; Lunzer, M.M.; Powers, M.D.; Sham, Y.Y.; Watanabe, Y.; Portoghese, P. Inhibition of inflammatory and neuropathic pain by targeting a mu opioid receptor/chemokine receptor 5 heteromer (MOR-CCR5). J. Med. Chem. 2015, 58, 8647-8657. [CrossRef]

81. Arnatt, C.K.; Falls, B.A.; Yuan, Y.; Raborg, T.J.; Masvekar, R.R.; El-Hage, N.; Selley, D.E.; Nicola, A.V.; Knapp, P.E.; Hauser, K.F.; et al. Exploration of bivalent ligands targeting putative mu opioid receptor and chemokine receptor CCR5 dimerization. Bioorg. Med. Chem. 2016, 24, 5969-5987. [CrossRef]

82. Ma, H.; Wang, H.; Li, M.; Barreto-De-Souza, V.; Reinecke, B.A.; Gunta, R.; Zheng, Y.; Kang, G.; Nassehi, N.; Zhang, H.; et al. Bivalent Ligand Aiming Putative Mu Opioid Receptor and Chemokine Receptor CXCR4 Dimers in Opioid Enhanced HIV-1 Entry. ACS Med. Chem. Lett. 2020, 11, 2318-2324. [CrossRef]

83. Huang, B.; Wang, H.; Zheng, Y.; Li, M.; Kang, G.; Barreto-De-Souza, V.; Nassehi, N.; Knapp, P.E.; Selley, D.E.; Hauser, K.F.; et al. Structure-Based Design and Development of Chemical Probes Targeting Putative MOR-CCR5 Heterodimers to Inhibit Opioid Exacerbated HIV-1 Infectivity. J. Med. Chem. 2021, 64, 7702-7723. [CrossRef]

84. Buch, S.; Yao, H.; Guo, M.-L.; Mori, T.; Su, T.-P.; Wang, J. Cocaine and HIV-1 Interplay: Molecular Mechanisms of Action and Addiction. J. Neuroimmune Pharmacol. 2011, 6, 503-515. [CrossRef]

85. Tyagi, M.; Weber, J.; Bukrinsky, M.; Simon, G.L. The effects of cocaine on HIV transcription. J. Neurovirol. 2016, 22, 261-274. [CrossRef]

86. Baum, M.K.; Rafie, C.; Lai, S.; Sales, S.; Page, B.; Campa, A. Crack-Cocaine Use Accelerates HIV Disease Progression in a Cohort of HIV-Positive Drug Users. JAIDS J. Acquir. Immune Defic. Syndr. 2009, 50, 93-99. [CrossRef]

87. Cook, J.A.; Burke-Miller, J.K.; Cohen, M.H.; Cook, R.L.; Vlahov, D.; Wilson, T.E.; Golub, E.T.; Schwartz, R.M.; Howard, A.A.; Ponath, C.; et al. Crack cocaine, disease progression, and mortality in a multicenter cohort of HIV-1 positive women. AIDS 2008, 22, 1355-1363. [CrossRef]

88. Carrico, A.W.; Johnson, M.O.; Morin, S.F.; Remien, R.H.; Riley, E.D.; Hecht, F.M.; Fuchs, D. Stimulant use is associated with immune activation and depleted tryptophan among HIV-positive persons on anti-retroviral therapy. Brain Behav. Immun. 2008, 22, 1257-1262. [CrossRef]

89. Dhillon, N.K.; Williams, R.; Peng, F.; Tsai, Y.-J.; Dhillon, S.; Nicolay, B.; Gadgil, M.; Kumar, A.; Buch, S.J. Cocaine-mediated enhancement of virus replication in macrophages: Implications for human immunodeficiency virus-associated dementia. $J$. Neurovirol. 2007, 13, 483-495. [CrossRef]

90. Swepson, C.; Ranjan, A.; Balasubramaniam, M.; Pandhare, J.; Dash, C. Cocaine Enhances HIV-1 Transcription in Macrophages by Inducing p38 MAPK Phosphorylation. Front. Microbiol. 2016, 7, 823. [CrossRef]

91. Sahu, G.; Farley, K.; El-Hage, N.; Aiamkitsumrit, B.; Fassnacht, R.; Kashanchi, F.; Ochem, A.; Simon, G.L.; Karn, J.; Hauser, K.F.; et al. Cocaine promotes both initiation and elongation phase of HIV-1 transcription by activating NF- $\kappa$ B and MSK1 and inducing selective epigenetic modifications at HIV-1 LTR. Virology 2015, 483, 185-202. [CrossRef]

92. Bagasra, O.; Pomerantz, R.J. Human Immunodeficiency Virus Type 1 Replication in Peripheral Blood Mononuclear Cells in the Presence of Cocaine. J. Infect. Dis. 1993, 168, 1157-1164. [CrossRef]

93. Napuri, J.; Pilakka-Kanthikeel, S.; Raymond, A.; Agudelo, M.; Yndart-Arias, A.; Saxena, S.K.; Nair, M. Cocaine Enhances HIV-1 Infectivity in Monocyte Derived Dendritic Cells by Suppressing microRNA-155. PLoS ONE 2013, 8, e83682. [CrossRef]

94. Peterson, P.K.; Gekker, G.; Chao, C.C.; Schut, R.; Verhoef, J.; Edelman, C.K.; Erice, A.; Balfour, H.H. Cocaine amplifies HIV-1 replication in cytomegalovirus-stimulated peripheral blood mononuclear cell cocultures. J. Immunol. 1992, 149, 676-680.

95. Reynolds, J.L.; Mahajan, S.D.; Bindukumar, B.; Sykes, D.; Schwartz, S.A.; Nair, M.P. Proteomic analysis of the effects of cocaine on the enhancement of HIV-1 replication in normal human astrocytes (NHA). Brain Res. 2006, 1123, 226-236. [CrossRef]

96. Gekker, G.; Hu, S.; Wentland, M.P.; Bidlack, J.M.; Lokensgard, J.R.; Peterson, P.K. k-Opioid Receptor Ligands Inhibit CocaineInduced HIV-1 Expression in Microglial Cells. J. Pharmacol. Exp. Ther. 2004, 309, 600-606. [CrossRef]

97. López, O.V.; Gorantla, S.; Segarra, A.C.; Norat, M.C.A.; Álvarez, M.; Skolasky, R.L.; Meléndez, L.M. Sigma-1 Receptor Antagonist (BD1047) Decreases Cathepsin B Secretion in HIV-Infected Macrophages Exposed to Cocaine. J. Neuroimmune Pharmacol. 2019, 14, 226-240. [CrossRef]

98. Mantri, C.K.; Dash, J.P.; Mantri, J.V.; Dash, C. Cocaine Enhances HIV-1 Replication in CD4+ T Cells by Down-Regulating MiR-125b. PLoS ONE 2012, 7, e51387. [CrossRef]

99. Mahajan, S.; Aalinkeel, R.; Reynolds, J.; Nair, B.L.; Fernandez, S.B.; Schwartz, S.F.; Nair, M.A. Morphine Exacerbates HIV-1 Viral Protein gp120 Induced Modulation of Chemokine Gene Expression in U373 Astrocytoma Cells. Curr. HIV Res. 2005, 3, 277-288. [CrossRef] 
100. Fiala, M.; Eshleman, A.J.; Cashman, J.; Lin, J.; Lossinsky, A.S.; Suarez, V.; Yang, W.; Zhang, J.; Popik, W.; Singer, E.; et al. Cocaine increases human immunodeficiency virus type 1 neuroinvasion through remodeling brain microvascular endothelial cells. $J$. Neurovirol. 2005, 11, 281-291. [CrossRef]

101. Roth, M.D.; Tashkin, D.P.; Choi, R.; Jamieson, B.D.; Zack, J.A.; Baldwin, G. Cocaine Enhances Human Immunodeficiency Virus Replication in a Model of Severe Combined Immunodeficient Mice Implanted with Human Peripheral Blood Leukocytes. J. Infect. Dis. 2002, 185, 701-705. [CrossRef] [PubMed]

102. Roth, M.D.; Whittaker, K.M.; Choi, R.; Tashkin, D.P.; Baldwin, G.C. Cocaine and -1 receptors modulate HIV infection, chemokine receptors, and the HPA axis in the huPBL-SCID model. J. Leukoc. Biol. 2005, 78, 1198-1203. [CrossRef] [PubMed]

103. Doke, M.; Jeganathan, V.; McLaughlin, J.P.; Samikkannu, T. HIV-1 Tat and cocaine impact mitochondrial epigenetics: Effects on DNA methylation. Epigenetics 2020, 1-20. [CrossRef] [PubMed]

104. Rodriguez, C.; Reynolds, A. Accessing the cure: Helping patients with hepatitis C overcome barriers to care. Am. J. Manag. Care 2016, 22, s108-s112. [PubMed]

105. Samikkannu, T.; Rao, K.V.; Ding, H.; Agudelo, M.; Raymond, A.D.; Yoo, C.; Nair, M.P. Immunopathogenesis of HIV Infection in Cocaine Users: Role of Arachidonic Acid. PLoS ONE 2014, 9, e106348. [CrossRef]

106. Han, B.; Compton, W.M.; Jones, C.M.; Einstein, E.B.; Volkow, N.D. Methamphetamine Use, Methamphetamine Use Disorder, and Associated Overdose Deaths among US Adults. JAMA Psychiatry 2021. [CrossRef]

107. Papageorgiou, M.; Raza, A.; Fraser, S.; Nurgali, K.; Apostolopoulos, V. Methamphetamine and its immune-modulating effects. Maturitas 2019, 121, 13-21. [CrossRef]

108. Massanella, M.; Gianella, S.; Schrier, R.; Dan, J.M.; Pérez-Santiago, J.; de Oliveira, M.F.; Richman, D.D.; Little, S.J.; Benson, C.A.; Daar, E.S.; et al. Methamphetamine Use in HIV-infected Individuals Affects T-cell Function and Viral Outcome during Suppressive Antiretroviral Therapy. Sci. Rep. 2015, 5, srep13179. [CrossRef]

109. Fulcher, J.A.; Shoptaw, S.; Makgoeng, S.B.; Elliott, J.; Ibarrondo, F.J.; Ragsdale, A.; Brookmeyer, R.; Anton, P.A.; Gorbach, P.M. Brief Report: Recent Methamphetamine Use Is Associated with Increased Rectal Mucosal Inflammatory Cytokines, Regardless of HIV-1 Serostatus. JAIDS J. Acquir. Immune Defic. Syndr. 2018, 78, 119-123. [CrossRef]

110. Harms, R.; Morsey, B.; Boyer, C.W.; Fox, H.S.; Sarvetnick, N. Methamphetamine Administration Targets Multiple Immune Subsets and Induces Phenotypic Alterations Suggestive of Immunosuppression. PLoS ONE 2012, 7, e49897. [CrossRef]

111. King, W.D.; Larkins, S.; Hucks-Ortiz, C.; Wang, P.-C.; Gorbach, P.M.; Veniegas, R.; Shoptaw, S. Factors Associated with HIV Viral Load in a Respondent Driven Sample in Los Angeles. AIDS Behav. 2009, 13, 145-153. [CrossRef]

112. Verhalen, B.; Starrett, G.J.; Harris, R.S.; Jiang, M. Functional Upregulation of the DNA Cytosine Deaminase APOBEC3B by Polyomaviruses. J. Virol. 2016, 90, 6379-6386. [CrossRef]

113. Ellis, R.J.; Childers, M.E.; Cherner, M.; Lazzaretto, D.; Letendre, S.; HIV Neurobehavioral Research Center Group. Increased Human Immunodeficiency Virus Loads in Active Methamphetamine Users Are Explained by Reduced Effectiveness of Antiretroviral Therapy. J. Infect. Dis. 2003, 188, 1820-1826. [CrossRef]

114. Cai, N.S.; Cadet, J.L. The combination of methamphetamine and of the HIV protein, Tat, induces death of the human neuroblastoma cell line, SH-SY5Y. Synapse 2008, 62, 551-552. [CrossRef]

115. Langford, D.; Grigorian, A.; Hurford, R.; Adame, A.; Crews, L.; Masliah, E. The role of mitochondrial alterations in the combined toxic effects of human immunodeficiency virus Tat protein and methamphetamine on calbindin positive-neurons. J. Neurovirol. 2004, 10, 327-337. [CrossRef]

116. Cen, P.; Ye, L.; Su, Q.-J.; Wang, X.; Li, J.-L.; Lin, X.-Q.; Liang, H.; Ho, W. Methamphetamine Inhibits Toll-Like Receptor 9-Mediated Anti-HIV Activity in Macrophages. AIDS Res. Hum. Retrovir. 2013, 29, 1129-1137. [CrossRef]

117. Mantri, C.K.; Mantri, J.V.; Pandhare, J.; Dash, C. Methamphetamine inhibits HIV-1 replication in CD4+ T cells by modulating anti-HIV-1 miRNA expression. Am. J. Pathol. 2014, 184, 92-100. [CrossRef]

118. Liang, H.; Wang, X.; Chen, H.; Song, L.; Ye, L.; Wang, S.-H.; Wang, Y.-J.; Zhou, L.; Ho, W.-Z. Methamphetamine Enhances HIV Infection of Macrophages. Am. J. Pathol. 2008, 172, 1617-1624. [CrossRef]

119. Lawson, K.S.; Prasad, A.; Groopman, J. Methamphetamine enhances HIV-1 replication in CD4+ T-cells via a novel IL-1b auto-regulatory loop. Front. Immunol. 2020, 11, 136. [CrossRef]

120. Nair, M.P.; Saiyed, Z.M.; Nair, N.; Gandhi, N.H.; Rodriguez, J.W.; Boukli, N.; Provencio-Vasquez, E.; Malow, R.M.; Miguez-Burbano, M. Methamphetamine enhances HIV-1 infectivity in monocyte derived dendritic cells. J. Neuroimmune Pharmacol. 2009, 4, 129-139. [CrossRef]

121. Nair, M.P.; Saiyed, Z.M. Effect of methamphetamine on expression of HIV coreceptors and CC-chemokines by dendritic cells. Life Sci. 2011, 88, 987-994. [CrossRef]

122. Prasad, A.; Kulkarni, R.; Shrivastava, A.; Jiang, S.; Lawson, K.; Groopman, J.E. Methamphetamine functions as a novel CD4+ T-cell activator via the sigma-1 receptor to enhance HIV-1 infection. Sci. Rep. 2019, 9, 958. [CrossRef]

123. Skowronska, M.; McDonald, M.; Velichkovska, M.; Leda, A.R.; Park, M.; Toborek, M. Methamphetamine increases HIV infectivity in neural progenitor cells. J. Biol. Chem. 2018, 293, 296-311. [CrossRef]

124. Toussi, S.S.; Joseph, A.; Zheng, J.H.; Dutta, M.; Santambrogio, L.; Goldstein, H. Methamphetamine Treatment Increases in Vitro and in Vivo HIV Replication. AIDS Res. Hum. Retrovir. 2009, 25, 1117-1121. [CrossRef]

125. Administration, S. Key Substance Use and Mental Health Indicators in the United States: Results from the 2019 National Survey on Drug Use and Health; HHS publication \#PEP20-07-01-001; NSDUH series H-55; FRU: Rockville, MD, USA, 2020. 
126. Baliunas, D.; Rehm, J.; Irving, H.; Shuper, P. Alcohol consumption and risk of incident human immunodeficiency virus infection: A meta-analysis. Int. J. Public Health 2010, 55, 159-166. [CrossRef]

127. Kiene, S.M.; Barta, W.D.; Tennen, H.; Armeli, S. Alcohol, Helping Young Adults to Have Unprotected Sex with Casual Partners: Findings from a Daily Diary Study of Alcohol Use and Sexual Behavior. J. Adolesc. Health 2009, 44, 73-80. [CrossRef]

128. Lee, K.; Hutton, H.E.; Lesko, C.R.; Monroe, A.K.; Alvanzo, A.; McCaul, M.E.; Chander, G. Associations of Drug Use, Violence, and Depressive Symptoms with Sexual Risk Behaviors among Women with Alcohol Misuse. Women's Health Issues 2018, 28, 367-374. [CrossRef]

129. La Flair, L.N.; Bradshaw, C.P.; Storr, C.L.; Green, K.M.; Alvanzo, A.A.; Crum, R.M. Intimate Partner Violence and Patterns of Alcohol Abuse and Dependence Criteria among Women: A Latent Class Analysis. J. Stud. Alcohol Drugs 2012, 73, 351-360. [CrossRef]

130. Lesko, C.R.; Lau, B.; Chander, G.; Moore, R.D. Time Spent with HIV Viral Load > 1500 Copies/mL among Persons Engaged in Continuity HIV Care in an Urban Clinic in the United States, 2010-2015. AIDS Behav. 2018, 22, 3443-3450. [CrossRef]

131. Williams, E.C.; Hahn, J.A.; Saitz, R.; Bryant, K.; Lira, M.C.; Samet, J.H. Alcohol Use and Human Immunodeficiency Virus (HIV) Infection: Current Knowledge, Implications, and Future Directions. Alcohol. Clin. Exp. Res. 2016, 40, 2056-2072. [CrossRef]

132. Samuelson, D.R.; Siggins, R.W.; Ruan, S.; Amedee, A.M.; Sun, J.; Zhu, Q.K.; Marasco, W.A.; Taylor, C.M.; Luo, M.; Welsh, D.A.; et al. Alcohol consumption increases susceptibility to pneumococcal pneumonia in a humanized murine HIV model mediated by intestinal dysbiosis. Alcohol 2019, 80,33-43. [CrossRef]

133. Jolley, S.E.; Alkhafaf, Q.; Hough, C.; Welsh, D.A. Presence of an Alcohol Use Disorder is Associated with Greater Pneumonia Severity in Hospitalized HIV-Infected Patients. Lung 2016, 194, 755-762. [CrossRef] [PubMed]

134. Shiu, C.; Barbier, E.; Di Cello, F.; Choi, H.J.; Stins, M. HIV-1 gp120 as Well as Alcohol Affect Blood-Brain Barrier Permeability and Stress Fiber Formation: Involvement of Reactive Oxygen Species. Alcohol. Clin. Exp. Res. 2007, 31, 130-137. [CrossRef] [PubMed]

135. Hsu, H.-Y.; Chang, M.-H.; Ni, Y.-H.; Chen, H. Survey of hepatitis B surface variant infection in children 15 years after a nationwide vaccination programme in Taiwan. Gut 2004, 53, 1499-1503. [CrossRef] [PubMed]

136. Liu, X.; Zha, J.; Nishitani, J.; Chen, H.; Zack, J.A. HIV-1 infection in peripheral blood lymphocytes (PBLs) exposed to alcohol. Virology 2003, 307, 37-44. [CrossRef]

137. Wang, X.; Douglas, S.D.; Metzger, D.S.; Guo, C.; Li, Y.; O’Brien, C.P.; Song, L.; Davis-Vogal, A.; Ho, W. Alcohol potentiates HIV-1 infection of human blood mononuclear phagocytes. Alcohol. Clin. Exp. Res. 2002, 26, 1880-1886. [CrossRef]

138. Zheng, J.; Yang, O.O.; Xie, Y.; Campbell, R.; Chen, I.S.; Pang, S. Ethanol Stimulation of HIV Infection of Oral Epithelial Cells. JAIDS J. Acquir. Immune Defic. Syndr. 2004, 37, 1445-1453. [CrossRef]

139. Wang, X.; Zhao, J.; Ragupathy, V.; Hewlett, I. The impact of ethanol on increasing HIV-1 replications in U1 cells. Clin. Res. HIV/AIDS 2018, 5, 1048.

140. Agudelo, M.; Figueroa, G.; Yndart, A.; Casteleiro, G.; Muñoz, K.; Samikkannu, T.; Atluri, V.; Nair, M.P. Alcohol and Cannabinoids Differentially Affect HIV Infection and Function of Human Monocyte-Derived Dendritic Cells (MDDC). Front. Microbiol. 2015, 6, 1452. [CrossRef]

141. Tang, B.; Li, Y.; Yuan, S.; Tomlinson, S.; He, S. Upregulation of the $\delta$ opioid receptor in liver cancer promotes liver cancer progression both in vitro and in vivo. Int. J. Oncol. 2013, 43, 1281-1290. [CrossRef]

142. Lu, J.; Liu, Z.; Zhao, L.; Tian, H.; Liu, X.; Yuan, C. In vivo and in vitro inhibition of human liver cancer progress by downregulation of the $\mu$-opioid receptor and relevant mechanisms. Oncol. Rep. 2013, 30, 1731-1738. [CrossRef]

143. Zhu, X.; Wang, L.-C.; Chen, E.-Q.; Chen, X.-B.; Chen, L.-Y.; Liu, L.; Lei, X.-Z.; Liu, C.; Tang, H. Prospective Evaluation of FibroScan for the Diagnosis of Hepatic Fibrosis Compared with Liver Biopsy/AST Platelet Ratio Index and FIB-4 in Patients with Chronic HBV Infection. Dig. Dis. Sci. 2011, 56, 2742-2749. [CrossRef]

144. Jia, K.; Sun, D.; Ling, S.; Tian, Y.; Yang, X.; Sui, J.; Tang, B.; Wang, L. Activated $\delta$-opioid receptors inhibit hydrogen peroxideinduced apoptosis in liver cancer cells through the PKC/ERK signaling pathwa. Mol. Med. Rep. 2014, 10, 839-847. [CrossRef]

145. De Minicis, S.; Candelaresi, C.; Marzioni, M.; Saccomano, S.; Roskams, T.; Casini, A.; Risaliti, A.; Salzano, R.; Cautero, N.; di Francesco, F.; et al. Role of endogenous opioids in modulating HSC activity in vitro and liver fibrosis in vivo. Gut 2008, 57, 352-364. [CrossRef]

146. Jaume, M.; Jacquet, S.; Cavaillès, P.; Macé, G.; Stephan, L.; Blanpied, C.; Demur, C.; Brousset, P.; Dietrich, G. Opioid receptor blockade reduces Fas-induced hepatitis in mice. Hepatology 2004, 40, 1136-1143. [CrossRef]

147. Ebrahimkhani, M.R.; Kiani, S.; Oakley, F.; Kendall, T.; Shariftabrizi, A.; Tavangar, S.M.; Moezi, L.; Payabvash, S.; Karoon, A.; Hoseininik, H.; et al. Naltrexone, an opioid receptor antagonist, attenuates liver fibrosis in bile duct ligated rats. Gut 2006, 55, 1606-1616. [CrossRef]

148. Bansal, M. Hepatic stellate cells: Fibrogenic, regenerative or both? Heterogeneity and context are key. Hepatol. Int. 2016, 10, 902-908. [CrossRef]

149. Ye, L.; Peng, J.S.; Wang, X.; Wang, Y.J.; Luo, G.X.; Ho, W.Z. Methamphetamine enhances Hepatitis C virus replication in human hepatocytes. J. Viral Hepat. 2008, 15, 261-270. [CrossRef]

150. Li, Y.; Zhang, T.; Douglas, S.D.; Lai, J.-P.; Xiao, W.-D.; Pleasure, D.E.; Ho, W.-Z. Morphine Enhances Hepatitis C Virus (HCV) Replicon Expression. Am. J. Pathol. 2003, 163, 1167-1175. [CrossRef]

151. Zhou, Y.; Sun, L.; Wang, X.; Zhou, L.; Li, J.; Liu, M.; Wang, F.; Peng, J.; Gui, X.; Zhao, H.; et al. Heroin use promotes HCV infection and dysregulates HCV-related circulating microRNAs. J. Neuroimmune Pharmacol. 2015, 10, 102-110. [CrossRef] 
152. Li, Y.; Ye, L.; Peng, J.-S.; Wang, C.-Q.; Luo, G.-X.; Zhang, T.; Wan, Q.; Ho, W. Morphine Inhibits Intrahepatic Interferon- $\alpha$ Expression and Enhances Complete Hepatitis C Virus Replication. J. Infect. Dis. 2007, 196, 719-730. [CrossRef]

153. Wang, C.-Q.; Li, Y.; Douglas, S.D.; Wang, X.; Metzger, D.S.; Zhang, T.; Ho, W.-Z. Morphine Withdrawal Enhances Hepatitis C Virus Replicon Expression. Am. J. Pathol. 2005, 167, 1333-1340. [CrossRef]

154. Zhu, H.; Geng, Y.; He, Q.; Li, M. miRNAs regulate immune response and signaling during hepatitis C virus infection. Eur. J. Med. Res. 2018, 23, 19. [CrossRef] [PubMed]

155. Operskalski, E.A.; Mack, W.J.; Strickler, H.D.; French, A.L.; Augenbraun, M.; Tien, P.C.; Villacres, M.C.; Spencer, L.Y.; DeGiacomo, M.; Kovacs, A. Factors associated with hepatitis C viremia in a large cohort of HIV-infected and -uninfected women. J. Clin. Virol. 2008, 41, 255-263. [CrossRef]

156. Conry-Cantilena, C.; VanRaden, M.; Gibble, J.; Melpolder, J.; Shakil, A.O.; Viladomiu, L.; Cheung, L.; DiBisceglie, A.; Hoofnagle, J.; Shih, J.W.; et al. Routes of Infection, Viremia, and Liver Disease in Blood Donors Found to Have Hepatitis C Virus Infection. N. Engl. J. Med. 1996, 334, 1691-1696. [CrossRef]

157. Winetsky, D.; Burack, D.; Antoniou, P.; Garcia, B.; Gordon, P.; Scherer, M. Psychosocial Factors and the Care Cascade for Hepatitis C Treatment Colocated at a Syringe Service Program. J. Infect. Dis. 2020, 222, S392-S400. [CrossRef]

158. Zarini, G.; Martinez, S.S.; Campa, A.; Sherman, K.; Tamargo, J.; Boyer, J.H.; Teeman, C.; Johnson, A.; Degarege, A.; Greer, P.; et al. Sex Differences, Cocaine Use, and Liver Fibrosis among African Americans in the Miami Adult Studies on HIV Cohort. J. Women's Health 2020, 29, 1176-1183. [CrossRef]

159. Martel-Laferrière, V.; Nitulescu, R.; Cox, J.; Cooper, C.; Tyndall, M.; Rouleau, D.; Walmsley, S.; Wong, L.; Klein, M.B.; for the Canadian Co-infection Cohort Study Investigators. Cocaine/crack use is not associated with fibrosis progression measured by AST-to-Platelet Ratio Index in HIV-HCV co-infected patients: A cohort study. BMC Infect. Dis. 2017, 17, 80. [CrossRef]

160. Tyson, G.L.; Kramer, J.R.; Duan, Z.; Davila, J.A.; Richardson, P.A.; El-Serag, H.B. Prevalence and predictors of hepatitis B virus coinfection in a United States cohort of hepatitis C virus-infected patients. Hepatology 2013, 58, 538-545. [CrossRef]

161. Jacka, B.; Applegate, T.; Krajden, M.; Olmstead, A.; Harrigan, P.R.; Marshall, B.D.; DeBeck, K.; Milloy, M.J.; Lamoury, F.; Pybus, O.G.; et al. Phylogenetic clustering of hepatitis C virus among people who inject drugs in Vancouver, Canada. Hepatology 2014, 60, 1571-1580. [CrossRef]

162. Hadland, S.E.; DeBeck, K.; Kerr, T.; Feng, C.; Montaner, J.S.; Wood, E. Prescription opioid injection and risk of hepatitis C in relation to traditional drugs of misuse in a prospective cohort of street youth. BMJ Open 2014, 4, e005419. [CrossRef]

163. Miller, C.L.; Kerr, T.; Fischer, B.; Zhang, R.; Wood, E. Methamphetamine Injection Independently Predicts Hepatitis C Infection among Street-Involved Youth in a Canadian Setting. J. Adolesc. Health 2009, 44, 302-304. [CrossRef]

164. Cunningham, E.B.; Jacka, B.; DeBeck, K.; Applegate, T.L.; Harrigan, P.R.; Krajden, M.; Marshall, B.D.L.; Montaner, J.; Lima, V.D.; Olmstead, A.D.; et al. Methamphetamine injecting is associated with phylogenetic clustering of hepatitis $\mathrm{C}$ virus infection among street-involved youth in Vancouver, Canada. Drug Alcohol Depend. 2015, 152, 272-276. [CrossRef] [PubMed]

165. Younossi, Z.M.; Zheng, L.; Stepanova, M.; Venkatesan, C.; Mir, H.M. Moderate, excessive or heavy alcohol consumption: Each is significantly associated with increased mortality in patients with chronic hepatitis C. Aliment. Pharmacol. Ther. 2013, 37, 703-709. [CrossRef] [PubMed]

166. Kim, N.J.; Pearson, M.; Vutien, P.; Su, F.; Moon, A.M.; Berry, K.; Green, P.K.; Williams, E.C.; Ioannou, G.N. Alcohol Use and Long-Term Outcomes among, U.S. Veterans Who Received Direct-Acting Antivirals for Hepatitis C Treatment. Hepatol. Commun. 2020, 4, 314-324. [CrossRef]

167. Bessesen, M.; Ives, D.; Condreay, L.; Lawrence, S.; Sherman, K. Chronic Active Hepatitis B Exacerbations in Human Immunodeficiency Virus-Infected Patients Following Development of Resistance to or Withdrawal of Lamivudine. Clin. Infect. Dis. 1999, 28, 1032-1035. [CrossRef]

168. Takahashi, K.; Takahashi, T.; Takahashi, S.; Watanabe, K.; Boku, S.; Matsui, S.; Arai, F.; Asakura, H. Difference in quasispecies of the hypervariable region 1 of hepatitis $C$ virus between alcoholic and non-alcoholic patients. J. Gastroenterol. Hepatol. 2001, 16, 416-423. [CrossRef]

169. McCartney, E.M.; Beard, M.R. Impact of alcohol on hepatitis C virus replication and interferon signaling. World J. Gastroenterol. 2010, 16, 1337-1343. [CrossRef]

170. Hou, W.; Bukong, T.N.; Kodys, K.; Szabo, G. Alcohol Facilitates HCV RNA Replication Via Up-Regulation of miR-122 Expression and Inhibition of Cyclin G1 in Human Hepatoma Cells. Alcohol. Clin. Exp. Res. 2013, 37, 599-608. [CrossRef]

171. Laskus, T.; Operskalski, E.A.; Radkowski, M.; Wilkinson, J.; Mack, W.J.; Degiacomo, M.; Al-Harthi, L.; Chen, Z.; Xu, J.; Kovacs, A. Negative-Strand Hepatitis C Virus (HCV) RNA in Peripheral Blood Mononuclear Cells from Anti-HCV-Positive/HIV-Infected Women. J. Infect. Dis. 2007, 195, 124-133. [CrossRef]

172. Bedogni, G.; Miglioli, L.; Masutti, F.; Ferri, S.; Castiglione, A.; Lenzi, M.; Crocè, L.S.; Granito, A.; Tiribelli, C.; Bellentani, S. Natural Course of Chronic HCV and HBV Infection and Role of Alcohol in the General Population: The Dionysos Study. Am. J. Gastroenterol. 2008, 103, 2248-2253. [CrossRef]

173. Larkin, J.; Clayton, M.M.; Liu, J.; Feitelson, M. Chronic ethanol consumption stimulates hepatitis B virus gene expression and replication in transgenic mice. Hepatology 2001, 34, 792-797. [CrossRef]

174. Ganne-Carrié, N.; Kremsdorf, D.; Garreau, F.; Thevenin, M.; Petit, M.-A.; Nalpas, B.; Bréchot, C. Effects of ethanol on hepatitis B virus Pre-S/S gene expression in the human hepatocellular carcinoma derived HEP G2 hepatitis B DNA positive cell line. J. Hepatol. 1995, 23, 153-159. [CrossRef] 
175. Pacek, L.R.; Crum, R.M. A review of the literature concerning HIV and cigarette smoking: Morbidity and mortality, associations with individual- and social-level characteristics, and smoking cessation efforts. Addict. Res. Theory 2015, 23, 10-23. [CrossRef]

176. Shuter, J.; Reddy, K.P.; Hyle, E.P.; Stanton, C.A.; Rigotti, N.A. Harm reduction for smokers living with HIV. Lancet HIV 2021, 8, e652-e658. [CrossRef]

177. Valiathan, R.; Miguez, M.J.; Patel, B.; Arheart, K.L.; Asthana, D. Tobacco Smoking Increases Immune Activation and Impairs T-Cell Function in HIV Infected Patients on Antiretrovirals: A Cross-Sectional Pilot Study. PLoS ONE 2014, 9, e97698. [CrossRef]

178. Ande, A.; McArthur, C.; Ayuk, L.; Awasom, C.; Achu, P.N.; Njinda, A.; Sinha, N.; Rao, P.S.S.; Agudelo, M.; Nookala, A.R.; et al. Effect of Mild-to-Moderate Smoking on Viral Load, Cytokines, Oxidative Stress, and Cytochrome P450 Enzymes in HIV-Infected Individuals. PLoS ONE 2015, 10, e0122402. [CrossRef]

179. Wojna, V.; Robles, L.; Skolasky, R.; Mayo, R.; Selnes, O.; De La Torre, T.; Maldonado, E.; Nath, A.; Meléndez, L.M.; LasaldeDominicci, J. Associations of cigarette smoking with viral immune and cognitive function in human immunodeficiency virusseropositive women. J. Neurovirol. 2007, 13, 561-568. [CrossRef]

180. Abbud, R.A.; Finegan, C.K.; Guay, L.A.; Rich, E.A. Enhanced Production of Human Immunodeficiency Virus Type 1 by In Vitro-Infected Alveolar Macrophages from Otherwise Healthy Cigarette Smokers. J. Infect. Dis. 1995, 172, 859-863. [CrossRef]

181. Zhao, L.; Li, F.; Zhang, Y.; Elbourkadi, N.; Wang, Z.; Yu, C.; Taylor, E.W. Mechanisms and genes involved in enhancement of HIV infectivity by tobacco smoke. Toxicology 2010, 278, 242-248. [CrossRef]

182. Rock, R.B.; Gekker, G.; Aravalli, R.N.; Hu, S.; Sheng, W.S.; Peterson, P.K. Potentiation of HIV-1 expression in microglial cells by nicotine: Involvement of transforming growth factor- $\beta 1$. J. Neuroimmune Pharmacol. 2008, 3, 143-149. [CrossRef]

183. Haque, S.; Sinha, N.; Ranjit, S.; Midde, N.M.; Kashanchi, F.; Kumar, S. Monocyte-derived exosomes upon exposure to cigarette smoke condensate alter their characteristics and show protective effect against cytotoxicity and HIV-1 replication. Sci. Rep. 2017, 7, 16120. [CrossRef] [PubMed]

184. Rao, P.; Ande, A.; Sinha, N.; Kumar, A.; Kumar, S. Effects of Cigarette Smoke Condensate on Oxidative Stress, Apoptotic Cell Death, and HIV Replication in Human Monocytic Cells. PLoS ONE 2016, 11, e0155791. [CrossRef] [PubMed]

185. Okafor, C.N.; Zhou, Z.; Ii, L.E.B.; Kelso, N.E.; Whitehead, N.E.; Harman, J.S.; Cook, C.; Cook, R.L. Marijuana use and viral suppression in persons receiving medical care for HIV-infection. Am. J. Drug Alcohol Abus. 2017, 43, 103-110. [CrossRef] [PubMed]

186. Kipp, A.M.; Rebeiro, P.F.; Shepherd, B.E.; Brinkley-Rubinstein, L.; Turner, M.; Bebawy, S.; Sterling, T.R.; Hulgan, T. Daily Marijuana Use is Associated with Missed Clinic Appointments among HIV-Infected Persons Engaged in HIV Care. AIDS Behav. 2017, 21, 1996-2004. [CrossRef]

187. Lake, S.; Kerr, T.; Capler, R.; Shoveller, J.; Montaner, J.; Milloy, M.-J. High-intensity cannabis use and HIV clinical outcomes among HIV-positive people who use illicit drugs in Vancouver, Canada. Int. J. Drug Policy 2017, 42, 63-70. [CrossRef]

188. Milloy, M.-J.; Marshall, B.; Kerr, T.; Richardson, L.; Hogg, R.; Guillemi, S.; Montaner, J.S.G.; Wood, E. High-intensity cannabis use associated with lower plasma human immunodeficiency virus-1 RNA viral load among recently infected people who use injection drugs. Drug Alcohol Rev. 2015, 34, 135-140. [CrossRef]

189. Chaillon, A.; Nakazawa, M.; Anderson, C.; Christensen-Quick, A.; Ellis, R.J.; Franklin, D.; Morris, S.R.; Gianella, S. Effect of Cannabis Use on Human Immunodeficiency Virus DNA during Suppressive Antiretroviral Therapy. Clin. Infect. Dis. 2020, 70, 140-143. [CrossRef]

190. Hurd, Y.L.; Yoon, M.; Manini, A.F.; Hernandez, S.; Olmedo, R.; Ostman, M.; Jutras-Aswad, D. Early Phase in the Development of Cannabidiol as a Treatment for Addiction: Opioid Relapse Takes Initial Center Stage. Neurotherapeutics 2015, 12, 807-815. [CrossRef]

191. Rizzo, M.D.; Henriquez, J.E.; Blevins, L.K.; Bach, A.; Crawford, R.B.; Kaminski, N.E. Targeting Cannabinoid Receptor 2 on Peripheral Leukocytes to Attenuate Inflammatory Mechanisms Implicated in HIV-Associated Neurocognitive Disorder. J. Neuroimmune Pharmacol. 2020, 15, 780-793. [CrossRef]

192. Maggirwar, S.B.; Khalsa, J.H. The Link between Cannabis Use, Immune System, and Viral Infections. Viruses 2021, 13, 1099. [CrossRef]

193. Nordmann, S.; Vilotitch, A.; Roux, P.; Esterle, L.; Spire, B.; Marcellin, F.; Salmon-Ceron, D.; Dabis, F.; Chas, J.; Rey, D.; et al. Daily cannabis and reduced risk of steatosis in human immunodeficiency virus and hepatitis $\mathrm{C}$ virus-co-infected patients (ANRS CO13-HEPAVIH). J. Viral Hepat. 2018, 25, 171-179. [CrossRef]

194. Becker, W.C.; Fiellin, D.A. When Epidemics Collide: Coronavirus Disease 2019 (COVID-19) and the Opioid Crisis. Ann. Intern. Med. 2020, 173, 59-60. [CrossRef]

195. N.V. COVID-19: Potential Implications for Individuals with Substance Use Disorders: National Institute of Drug Abuse. 2020. Available online: https:/ / www.drugabuse.gov/about-nida/noras-blog/2020/04/covid-19-potential-implications-individualssubstance-use-disorders (accessed on 22 August 2021).

196. Friedman, J.; Akre, S. COVID-19 and the Drug Overdose Crisis: Uncovering the Deadliest Months in the United States, JanuaryJuly 2020. Am. J. Public Health 2021, 111, 1284-1291. [CrossRef]

197. DiGennaro, C.; Garcia, G.-G.P.; Stringfellow, E.J.; Wakeman, S.; Jalali, M.S. Changes in characteristics of drug overdose death trends during the COVID-19 pandemic. Int. J. Drug Policy 2021, 98, 103392. [CrossRef]

198. Macmadu, A.; Batthala, S.; Gabel, A.M.C.; Rosenberg, M.; Ganguly, R.; Yedinak, J.L.; Hallowell, B.D.; Scagos, R.P.; Samuels, E.A.; Cerdá, M.; et al. Comparison of Characteristics of Deaths from Drug Overdose before vs. during the COVID-19 Pandemic in Rhode Island. JAMA Netw. Open 2021, 4, e2125538. [CrossRef] 
199. Rodda, L.N.; West, K.L.; Lesaint, K.T. Opioid Overdose-Related Emergency Department Visits and Accidental Deaths during the COVID-19 Pandemic. J. Urban Health 2020, 97, 808-813. [CrossRef]

200. Wang, Q.Q.; Kaelber, D.C.; Xu, R.; Volkow, N.D. COVID-19 risk and outcomes in patients with substance use disorders: Analyses from electronic health records in the United States. Mol. Psychiatry 2021, 26, 30-39. [CrossRef]

201. Morin, K.A.; Acharya, S.; Eibl, J.K.; Marsh, D.C. Evidence of increased Fentanyl use during the COVID-19 pandemic among opioid agonist treatment patients in Ontario, Canada. Int. J. Drug Policy 2021, 90, 103088. [CrossRef]

202. Niles, J.K.; Gudin, J.; Radcliff, J.; Kaufman, H.W. The Opioid Epidemic within the COVID-19 Pandemic: Drug Testing in 2020. Popul. Health Manag. 2021, 24, S43-S51. [CrossRef]

203. Dolati-Somarin, A.; Abd-Nikfarjam, B. The Reasons for Higher Mortality Rate in Opium Addicted Patients with COVID-19: A Narrative Review. Iran. J. Public Health 2021, 50, 470-479. [CrossRef]

204. Suzuki, S.; Carlos, M.P.; Chuang, L.F.; Torres, J.V.; Doi, R.H.; Chuang, R.Y. Methadone induces CCR5 and promotes AIDS virus infection. FEBS Lett. 2002, 519, 173-177. [CrossRef]

205. Peterson, P.K.; Sharp, B.M.; Gekker, G.; Portoghese, P.S.; Sannerud, K.; Balfour, H.H., Jr. Morphine promotes the growth of HIV-1 in human peripheral blood mononuclear cell cocultures. AIDS 1990, 4, 869-873. [CrossRef]

206. Ho, W.-Z.; Guo, C.; Yuan, C.-S.; Douglas, S.D.; Moss, J. Methylnaltrexone Antagonizes Opioid-Mediated Enhancement of HIV Infection of Human Blood Mononuclear Phagocytes. J. Pharmacol. Exp. Ther. 2003, 307, 1158-1162. [CrossRef]

207. Homan, J.W.; Steele, A.D.; Martinand-Mari, C.; Rogers, T.J.; Henderson, E.E.; Charubala, R.; Pfleiderer, W.; Reichenbach, N.L.; Suhadolnik, R.J. Inhibition of morphine-potentiated HIV-1 replication in peripheral blood mononuclear cells with the nuclease-resistant 2-5A agonist analog, 2-5A(N6B). J. Acquir. Immune Defic. Syndr. 2002, 30, 9-20. [CrossRef]

208. Wang, X.; Tan, N.; Douglas, S.D.; Zhang, T.; Wang, Y.-J.; Ho, W.-Z. Morphine inhibits CD8+ T cell-mediated, noncytolytic, anti-HIV activity in latently infected immune cells. J. Leukoc. Biol. 2005, 78, 772-776. [CrossRef]

209. Springer, S.A.; Di Paola, A.; Azar, M.M.; Barbour, R.; Biondi, B.; Desabrais, M.; Lincoln, T.; Skiest, D.J.; Altice, F. Extended-Release Naltrexone Improves Viral Suppression among Incarcerated Persons Living with HIV with Opioid Use Disorders Transitioning to the Community: Results of a Double-Blind, Placebo-Controlled Randomized Trial. JAIDS J. Acquir. Immune Defic. Syndr. 2018, 78, 43-53. [CrossRef] [PubMed]

210. Macías, J.; Morano, L.E.; Téllez, F.; Granados, R.; Rivero-Juárez, A.; Palacios, R.; Ríos, M.; Merino, D.; Pérez-Pérez, M.; Collado, A.; et al. Response to direct-acting antiviral therapy among ongoing drug users and people receiving opioid substitution therapy. $J$. Hepatol. 2019, 71, 45-51. [CrossRef] [PubMed]

211. Ing Lorenzini, K.; Girardin, F. Direct-acting antiviral interactions with opioids, alcohol or illicit drugs of abuse in HCV-infected patients. Liver Int. 2020, 40, 32-44. [CrossRef] [PubMed]

212. Burgess, S.; Partovi, N.; Yoshida, E.M.; Erb, S.R.; Azalgara, V.M.; Hussaini, T. Drug interactions with direct-acting antivirals for hepatitis C: Implications for HIV and transplant patients. Ann. Pharmacother. 2015, 49, 674-687. [CrossRef] [PubMed]

213. Gruber, V.A.; McCance-Katz, E.F. Methadone, Buprenorphine, and Street Drug Interactions with Antiretroviral Medications. Curr HIV/AIDS Rep. 2010, 7, 152-160. [CrossRef] [PubMed]

214. Gessain, A.; Cassar, O. Epidemiological aspects and world distribution of HTLV-1 infection. Front. Microbiol. 2012 , 3 , 388. [CrossRef] 